GEOLOGY OF GREENLAND SURVEYBULLETIN I $79 \cdot 1998$

The Citronen Fjord massive sulphide deposit, Peary Land, North Greenland: discovery, stratigraphy, mineralization and structural setting

Frank W. van der Stijl and Greg Z. Mosher 


\section{Geology of Greenland Survey Bulletin 179}

\section{Keywords}

Citronen Fjord, SEDEX deposit, Cambro-Silurian, Franklinian Basin, Peary Land, North Greenland, massive sulphides, gossans, starved basin, carbonate debris flows, sub-basin setting, shelf-trough junction, regional tectonics.

\section{Cover}

Low cloud and mist shroud the land on the eve of the discovery of the Citronen Fjord massive sulphide deposit in May 1993. The deposit was found during regional reconnaissance using low-cost logistics, viz. a skidoo-sledge expedition using the fjord ice. Primary targets were the reported gossans and sulphide showings in the Lower Palaeozoic sediments at Citronen Fjord. The scene shows the company Platinova's arrival at the mouth of Citronen Fjord, looking south into the fjord with low-lying marine terraces visible at its head. Massive sulphides were encountered on the first-day of exploration in the low cloud-covered hills of the Discovery area (left background). The height of the mountain on the right is about $850 \mathrm{~m}$. Photo: Stefan Bernstein, 17th May, 1993.

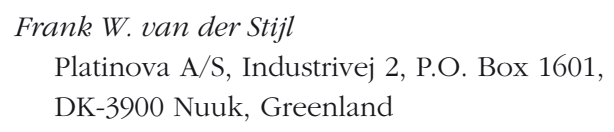

The colour reproductions are partly financed by Platinova A/S

ISBN 87-7871-042-1

ISSN 1397-1905

\section{Geology of Greenland Survey Bulletin}

The series Geology of Greenland Survey Bulletin is a continuation of Bulletin Grønlands Geologiske Undersøgelse and incorporates Rapport Grønlands Geologiske Undersøgelse.

\section{Citation of the name of this series:}

It is recommended that the name of this series is cited in full, viz. Geology of Greenland Survey Bulletin

If abbreviation of this volume is necessary the following form is suggested: Geology Greenland Surv. Bull. 179, 40 pp.

\section{Available from:}

Geological Survey of Denmark and Greenland

Thoravej 8, DK-2400 Copenhagen NV, Denmark

Phone: +45381420 00, fax: +45381420 50, e-mail: geus@geus.dk

or

Geografforlaget ApS

Fruerhøjvej 43, DK-5464 Brenderup, Denmark

Phone: +45644426 83, fax: +4564441697, e-mail: go@geografforlaget.dk 


\section{Contents}

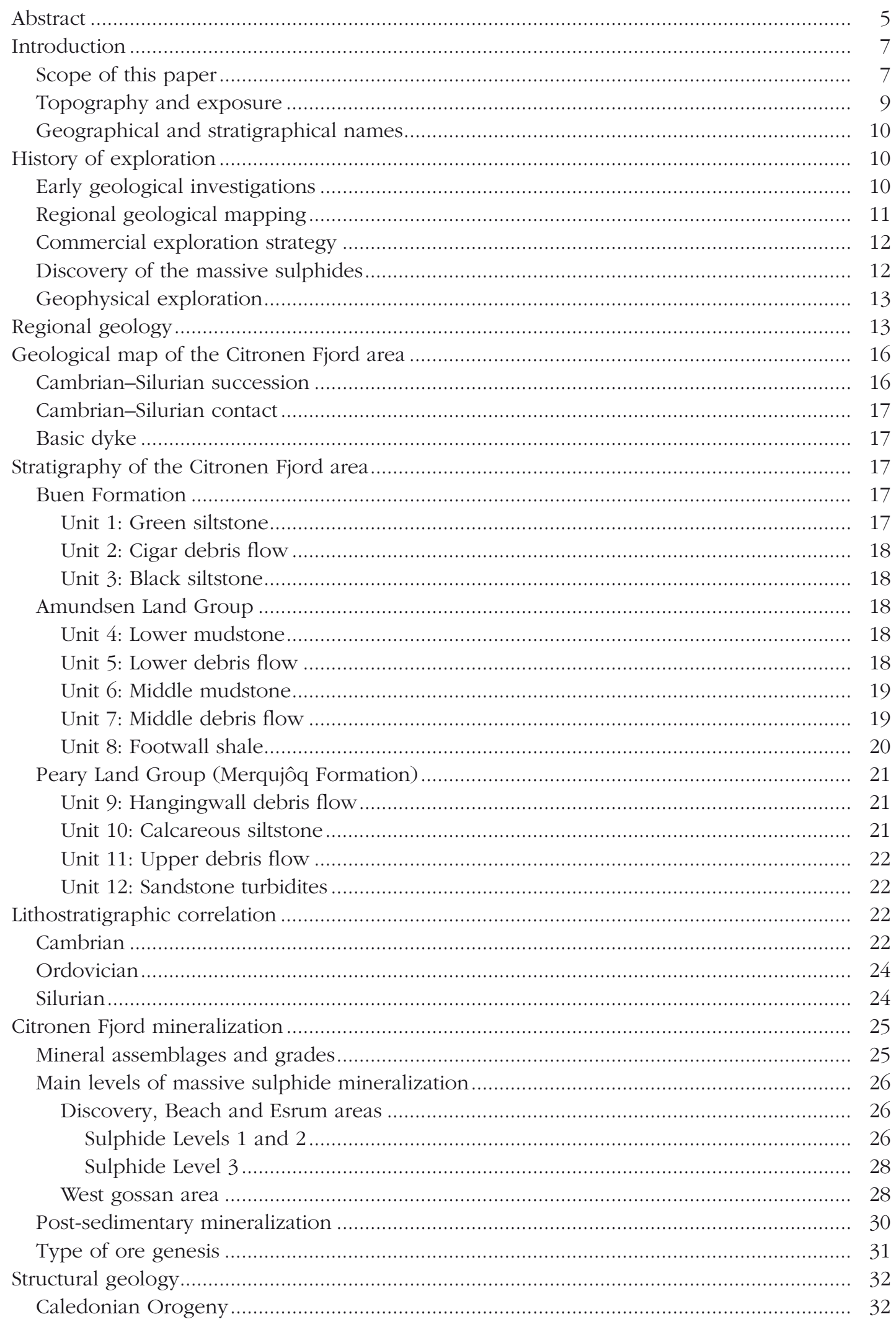


Ellesmerian Orogeny

Harder Fjord Fault Zone

Trolle Land Fault Zone 33

Structural elements in the Citronen Fjord area 34

General fold style 34

Thrust faults 35

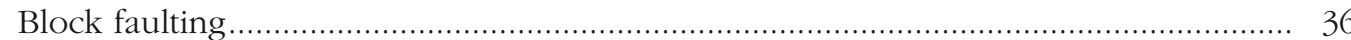

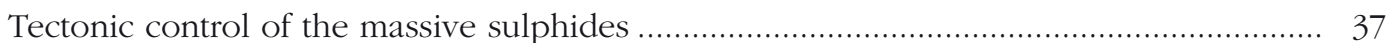

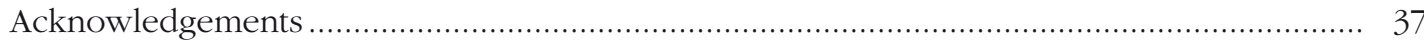

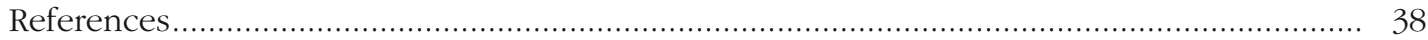


Van der Stijl, F.W. \& Mosher, G.Z. 1998: The Citronen Fjord massive sulphide deposit, Peary Land, North Greenland: discovery, stratigraphy, mineralization and structural setting.

Geology of Greenland Survey Bulletin 179, 40 pp.

The Citronen Fjord massive sulphide deposit in the Lower Palaeozoic of North Greenland is the world's most northerly base metal mineralization. Since discovery in 1993, it has been intensively investigated by geological and geophysical surveys, and by drilling. The deposit is generally flat lying with a thickness up to $50 \mathrm{~m}$; it extends from outcrop level to depths of $300 \mathrm{~m}$.

Three main stratiform sulphide sheets occur within a $200 \mathrm{~m}$ thick stratigraphic sequence; these are composed of massive and bedded pyrite with variable amounts of sphalerite and minor galena. The proven mineralization is continuous over a strike length of at least $3 \mathrm{~km}$ with a maximum width of $500 \mathrm{~m}$; an additional $5 \mathrm{~km}$ of mineralization along the same trend is suggested by geological mapping and gravity surveys. The total tonnage of sulphides is estimated to exceed 350 million tons. The overall base metal resource is estimated at 20 million tons of 7 per cent zinc, with a higher grade core of 7 million tons containing 9 per cent zinc and 1 per cent lead.

The Citronen Fjord deposit is located at the eastern end of the Palaeozoic Franklinian Basin that extends through the Arctic Islands of Canada and across northern Greenland. Its discovery is an example of a successful exploration strategy based on regional evaluation, sparse but telltale surface mineralization observations and low-cost logistics: a skidoo-sledge expedition. The stratiform mineralization is hosted in the dark argillaceous rocks of the Amundsen Land Group of latest Ordovician to Early Silurian age that comprises a starved basin sequence of cherts and shales with siltstones and mudstones, punctuated by carbonate debris flow conglomerates derived from the nearby southern carbonate shelf. The Lower Palaeozoic strata at Citronen Fjord are part of the southern margin of the North Greenland Fold Belt characterized by southerlyfacing folds and thrust faults.

A new geological map of the Citronen Fjord area is presented featuring Cambrian, Ordovician and Silurian strata, with two north-south cross-sections illustrating the main structure. Twelve informally-named lithostratigraphic units are recognized and comments given on correlation to the regional stratigraphy. Tectonic contacts separate Lower Cambrian strata from the Ordovician-Silurian part of the succession. It is concluded that the Citronen Fjord stratigraphy could be of local development in a sub-basin controlled by syn-genetic faults.

The lead-zinc deposit is interpreted to be of sedimentary-exhalative origin formed by the precipitation of sulphides from metal-bearing fluids introduced onto the sea-floor through underlying fractures. The significant components of this deposition model include the existence of a tensional tectonic regime, deep-seated fractures and a restricted sub-basin morphology. Massive to dendritic-textured pyrite is interpreted to represent vent-facies deposition while the bedded sulphides are taken to be the corresponding distal facies. The precise tectonic control of the fractures is debatable, as is the role of the so-called Navarana Fjord Escarpment - a palaeo-topographic feature marking the junction between shelf and trough that is assumed to lie immediately to the south of the Citronen Fjord.

\section{Authors' addresses:}

F.W.S., Platinova A/S, Industrivej 2, P.O. Box 1601, DK-3900 Nuuk, Greenland.

G.Z.M., Consulting geologist, 1820-29th Street, West Vancouver, British Columbia V7V 4M8, Canada. 

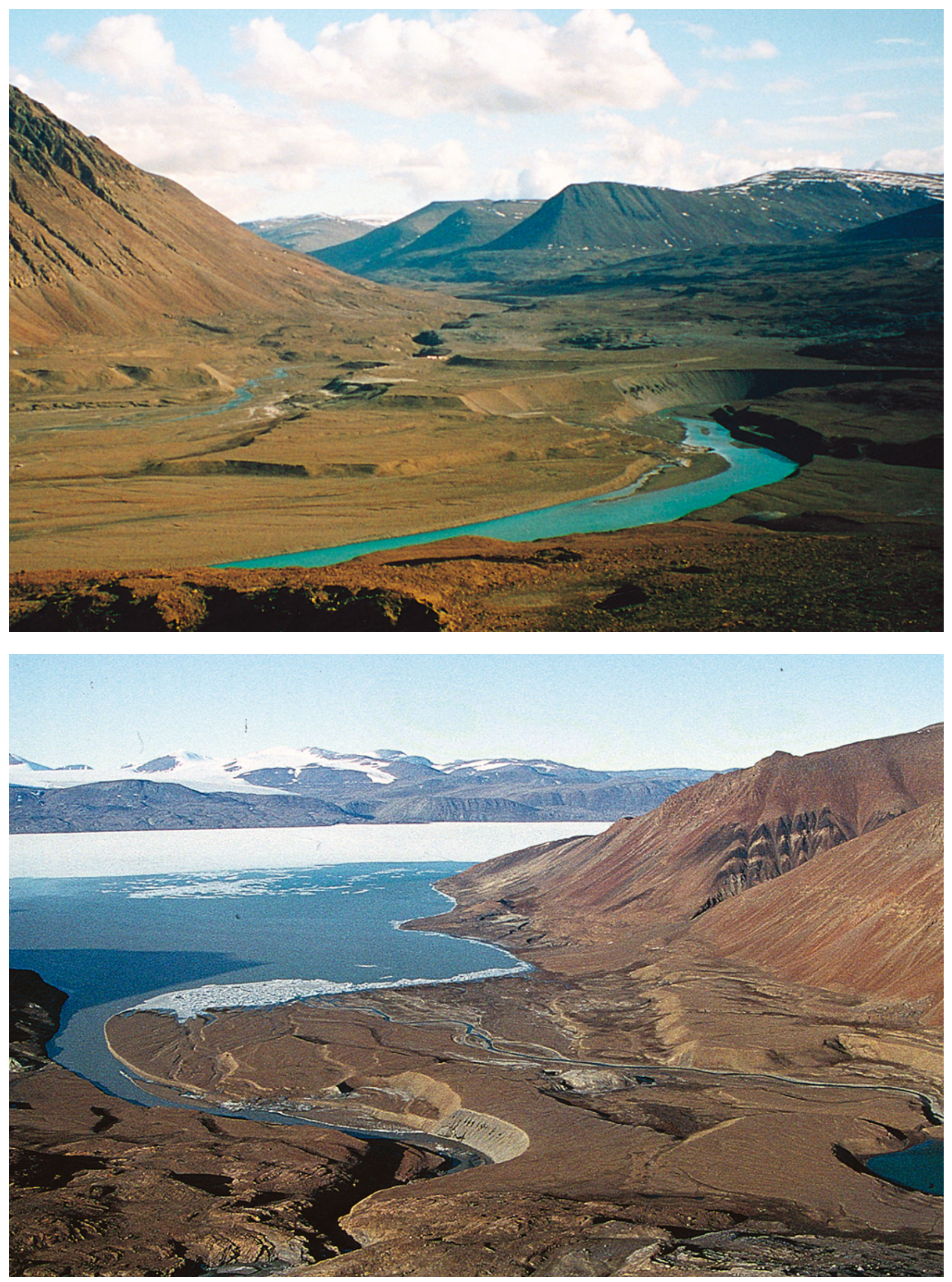


\section{Introduction}

The Citronen Fjord massive sulphide deposit is located at the fjord of that name on the south side of Frederick E. Hyde Fjord in northern Peary Land, North Greenland (Figs 1-3). Citronen Fjord is situated some $250 \mathrm{~km}$ north-west of the Danish military support base Station Nord and $100 \mathrm{~km}$ south-east of Kap Morris Jesup, the northern cape of Greenland. The location at $83^{\circ} 05^{\prime} \mathrm{N}$ and $28^{\circ} 15^{\prime} \mathrm{W}$ makes it the most northerly base metal mineralization presently known in the world. The mineral deposit was discovered in May 1993 by Platinova A/S during a reconnaissance exploration programme and it has been investigated by mapping, drilling and geophysical surveys during the period 1993-1997.

The distribution of sulphides in the area was initially defined by gravity and electromagnetic surveys and subsequently tested by an extensive programme of core drilling which demonstrated the occurrence of a continuous mineralization over a strike length of three kilometres with a maximum width of about $500 \mathrm{~m}$. Geological mapping and gravity data suggest that the mineralized trend in the area of initial discovery - herein called the Discovery area - continues for an additional five kilometres towards the sulphide exposures near the north-western corner of Citronen Fjord.

\section{Scope of this paper}

The massive sulphide deposit occurs within the Lower Palaeozoic strata of the Franklinian Basin that occupies the northernmost part of Greenland and is continuous across the Canadian Arctic Islands to the Beaufort Sea (Fig. 2). Regional geological maps of the Franklinian Basin are part of the 1:500 000 scale 'Geological map of Greenland' and Citronen Fjord appears on the Peary Land sheet (Bengaard \& Henriksen 1986a; Henriksen 1992). No detailed geological maps of the
Citronen Fjord area have been published and the nearest 1:100 000 scale map is the Nordkronen sheet (Pedersen \& Henriksen 1986) covering an area at the head of Frederick E. Hyde Fjord. The north-eastern corner of this sheet is $30 \mathrm{~km}$ from Citronen Fjord.

An important part of Platinova's exploration at Citronen Fjord has been the detailed geological mapping of the sulphide body and its immediate environs. This paper presents a simplified edition of the surface geological map, and gives cross-sections to illustrate the general structure (see Figs 5, 6). On the basis of these, the stratigraphy and structural characteristics of the area are discussed. The massive sulphide deposit is described in general terms, including its stratigraphical and regional setting; the various mineralization types are described with comments on their genesis and tectonic control.

As might be imagined, five years of continuous exploration has led to the accumulation of substantial data sets, particularly those gained from the geophysics and drilling programmes. At the time of writing (summer 1997) these data sets are being used in an economic assessment of the exploitation aspects of the deposit, and will not be released to the public. The data are, however, mentioned in this account in so far as the information is relevant to the general descriptions and interpretation. A short description of the main geophysical methods is given and pertinent drill-holes are included on the cross-section (see Fig. 6).

The discovery of the massive suphide deposit at Citronen Fjord is an illustrative example of a successful exploration strategy in the High Arctic, based on regional evaluation of a continental-scale sedimentary basin, sparse but tell-tale mineralization data and on low-cost logistics (MINEX 1993). To illustrate this aspect of the study, a history of exploration in the Citronen Fjord area is given, together with the exploration strat-

Fig. 1. The location and environs of the Citronen Fjord massive sulphide deposit. Upper: view south up the Citronen Fjord valley with Esrum Elv and the gravel terraces of the Beach area in the foreground. The river canyon in the centre is that of 'Citronen Elv' and the gossans of the Discovery area are on the lower mountain slopes in the distance to the east of 'Citronen Elv' (see Fig. 19). The distant mountains are composed of homoclinal Silurian sandstone turbidites of the Peary Land Group with the height of the plateau surface at around 750 m. Photo: August 1995. Lower: view north over Esrum Elv, Citronen Fjord (open) and Frederick E. Hyde Fjord (ice covered) to the snow-clad mountains of Johannes V. Jensen Land that are up to $1200 \mathrm{~m}$ high. The dark exposures on the north side of the gully 'East Elv' visible on the right are of the Cambrian Buen Formation (pale bands are the Cigar debris flow) in thrust fault contact above and below with units of the Silurian Merquiôq Formation (see Figs 5, 6). The top of the cliff is about $850 \mathrm{~m}$. Photo: late July 1993. 


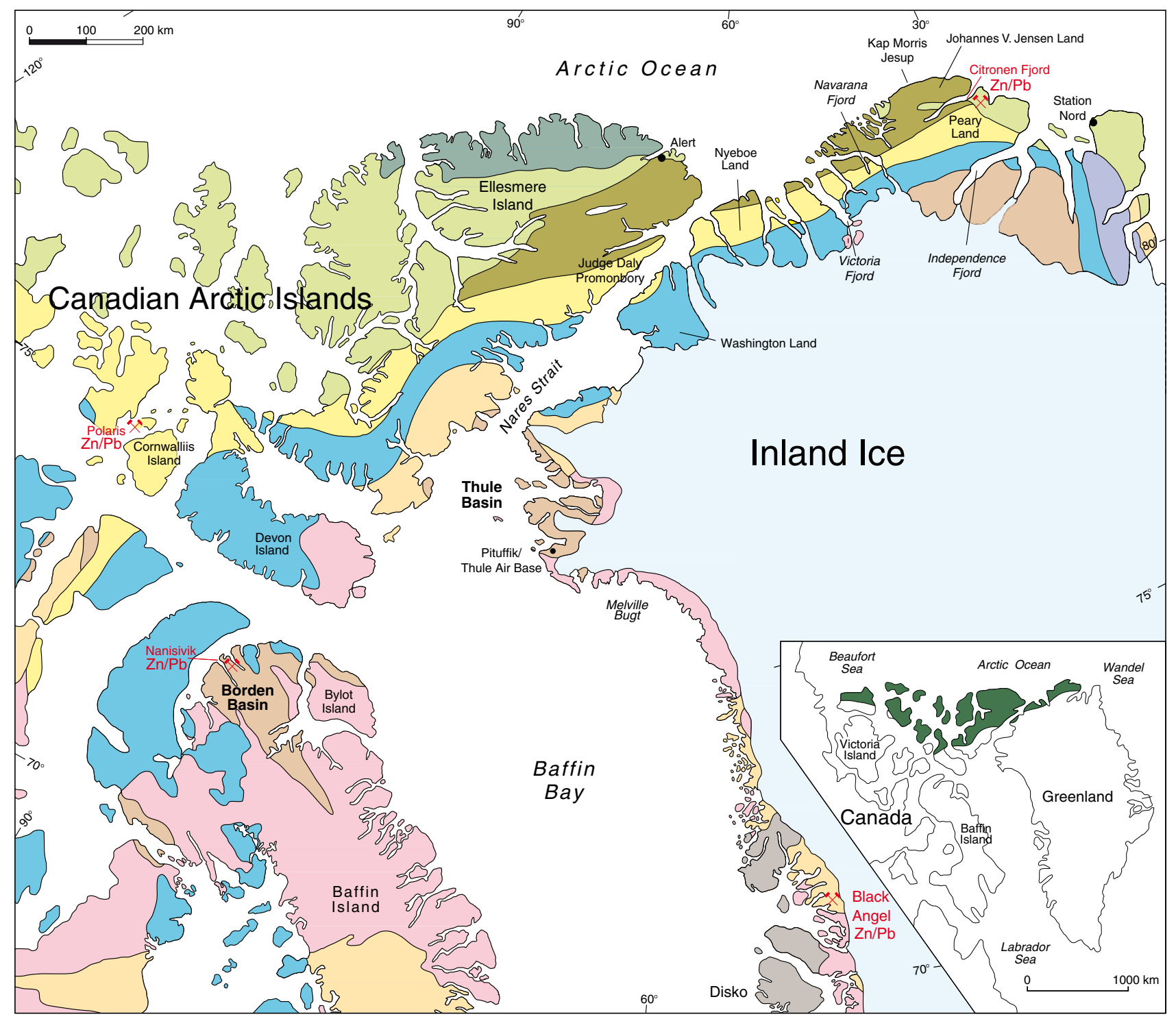

$\square$ Caledonian: Proterozoic-Palaeozoic

Pearya: Proterozoic-Palaeozoic

Intracratonic mid-late Proterozoic

Early Proterozoic crust

Archaean \& reworked Archaean

Tertiary volcanic province

Late Palaeozoic-Tertiary

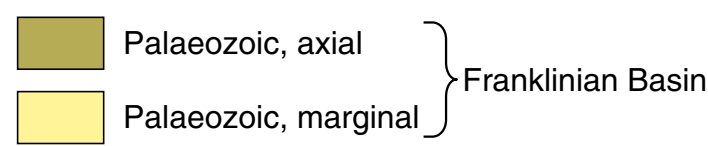

Palaeozoic, stable shelf-platform

Fig. 2. Geological map of northern Greenland and adjacent parts of the Canadian Arctic Islands showing the location of Citronen Fjord in north-eastern Peary Land. The zinc-lead mines of Nanisivik and Polaris in Canada - in the Proterozoic Borden Basin and Palaeozoic Franklinian Basin respectively - and the abandoned Black Angel mine in the Precambrian shield of West Greenland, are also shown. The Citronen Fjord massive sulphide deposit is situated at the boundary between the southern platform and shelf (marked 'marginal') and northern deep water trough (marked 'axial') of the Franklinian Basin. The inset map shows in green colour the extent of the Franklinian Basin stretching for $2500 \mathrm{~km}$ from the Beaufort Sea to the Wandel Sea. Modified from Dawes (1994). 
Fig. 3. Location map of the Citronen Fjord area showing the outline of the mineralization levels, main gossans, gravity anomaly trends, and the mineralized zone XX. CFM marks the type locality of the Citronens Fjord Member of Hurst \& Surlyk (1982). A geological map of the same area is given in Fig. 5.

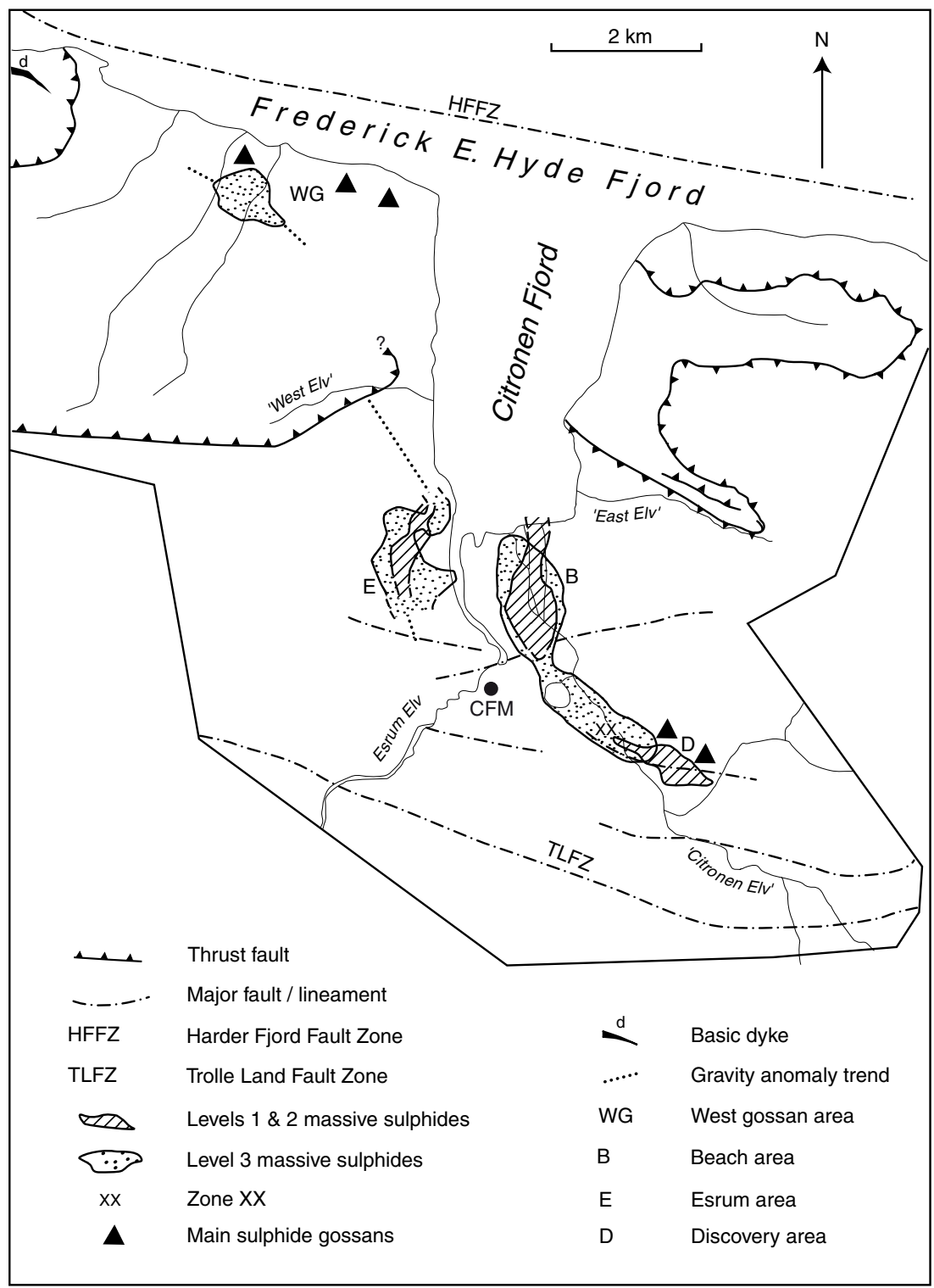

egy that, combined, led to the discovery of the massive sulphide deposit in 1993.

\section{Topography and exposure}

Physiographically, the Citronen Fjord area is part of the 'foreland ranges' of Davies (1972) being composed of heavily glaciated, dissected plateau and rolling hill landscape, with widespread glacial and glaciofluvial deposits. Mountains around Citronen Fjord are between 700 and $1000 \mathrm{~m}$ high, and these, particularly to the south where the rocks are homoclinal, show a well-developed plateau surface (Fig. 1).

The area at the head of Citronen Fjord is character- ized by a broad delta formed by two major rivers which transect an extensive sequence of raised beaches that border the delta (Fig. 1; see also section 'Geographical and stratigraphical names', p. 10). The delta valley itself is several kilometres wide and surrounded by high mountains; most of the area in which the mineralization occurs is between sea level and $c .150 \mathrm{~m}$. The northerly limit of the Inland Ice is about $150 \mathrm{~km}$ to the south (Fig. 2) but small ice-fields and ice-caps are common in the highest parts of the area. Frederick E. Hyde Fjord and adjoining fjords are frozen most of the year but for a short period in the summer (up to 6 weeks), Citronen Fjord and the inner part of Frederick E. Hyde Fjord open up (Fig. 1). However, drifting ice can occur until the fjords freeze again in September. 


\section{Geographical and stratigraphical names}

There are few authorized names for geographic features in this part of North Greenland and, since the region is uninhabited, there are no Greenlandic place names. Hans Egede Land is the land area south of Frederick E. Hyde Fjord, in which Citronen Fjord is located (see Fig. 22). Apart from these three names, the only other feature formally named in our study area is Esrum Elv, the western of the two rivers reaching the head of Citronen Fjord (Figs 1, 3). Thus for convenience of description in this paper, the three other rivers entering Citronen Fjord are informally named, viz. 'Citronen Elv', 'West Elv' and 'East Elv'; the inverted

\section{History of exploration}

\section{Early geological investigations}

The early knowledge of the geology of the area around Frederick E. Hyde Fjord is derived from information and samples collected by the Danmark Expedition in 1906-1907 (Bøggild 1917), the Danish Peary Land Expedition 1947-1950 (Ellitsgaard-Rasmussen 1955) and an expedition organized by Lauge Koch in 1953 (Fränkl 1955). Although the precise locality in Frederick E. Hyde Fjord is not known, it should be noted in this, the first published exploration history of the Citronen Fjord area, that one crushed shale sample with veins of quartz and calcite collected by Eigil Knuth in 1950, was reported to contain "centimetre-large polycrystalline pyrite balls" (Ellitsgaard-Rasmussen 1955, p. 44). This is the first mention in the literature of sulphides in the Frederick E. Hyde Fjord area.

The first indication of actual mineralization in the Frederick E. Hyde Fjord region was reported in 1960. It was made by W.E. Davies of the U.S. Geological Survey, who, during the first helicopter operation in Peary Land, noted gossans to the south of Frederick E. Hyde Fjord, referring specifically to Depotbugt $(20 \mathrm{~km}$ east of Citronen Fjord, see Fig. 22) where "there are extreme plays of color and every appearance of mineralisation" (personal and written communications to the Geological Survey of Greenland 1969). commas indicate the informal status of these names (Fig. 3).

The authorized name of the small fjord forming the location of this study is Citronen Fjord. The fjord was named by the Danish Peary Land Expedition (1947-50) and it was originally authorized as Citronens Fjord (Laursen 1972). This form was in use in the 1970s when the fjord's name was adopted in a formal stratigraphic sense, in the name Citronens Fjord Member (Hurst \& Surlyk 1982; see p. 11). In accordance with the Code of Stratigraphic Nomenclature (Hedberg 1976; Salvador 1994), in such cases the original name form must be retained in geological usage and thus, the type section of the Citronens Fjord Member is at Citronen Fjord (Fig. 3).
In 1969, during the British Joint Services Expedition, a multi-disciplinary, spring-summer skidoo expedition to Johannes $\mathrm{V}$. Jensen Land (northernmost part of Peary Land; Fig. 2), the Depotbugt gossan, noted from the air by Davies, was checked (Dawes 1969). In addition several gossans on the shore of Frederick E. Hyde Fjord just west of Citronen Fjord were observed (marked 'West gossan area' on Fig. 3). One of these was investigated and found to be hosted in a carbonate breccio-conglomerate with sulphide mineralization associated with intense calcite veining. Other conspicuous limestone breccio-conglomerate beds were noted in cliffs on the western coast of Citronen Fjord. One recumbently folded unit within dark shales and siltstones and overlain by a thick succession of calcareous sandstones was sampled and subsequently dated from its shelly fauna as early Silurian in age (Dawes 1969; Bjerreskov \& Poulsen 1973; Dawes \& Soper 1979; Fig. 4).

The two limestone breccio-conglomerate units noted in 1969, interpreted as platform-shelf edge debris flows, are the Middle debris flow (Unit 7) and Hangingwall debris flow (Unit 9) of this paper (see under 'Stratigraphy of the Citronen Fjord area', p. 17). The gossans at Depotbugt and Citronen Fjord were sampled but no indications of significant mineralization were recorded (P.R. Dawes, personal communication 1993). 
Fig. 4. Typical, brown to rusty-weathered bedrock exposure at Citronen Fjord showing resistent and recumbentlyfolded, limestone debris flow conglomerate - the Hangingwall debris flow of this paper - within calcareous siltstones on the west side of Citronen Fjord. These fossiliferous Silurian beds and the south-facing structure, described by Dawes \& Soper (1979), are part of the Citronens Fjord Member of Hurst \& Surlyk (1982). Annotation: 8, Footwall shale; 9, Hangingwall debris flow; 10, Calcareous siltstone. Height of sea cliff to left is about $100 \mathrm{~m}$; height of mountain is about $950 \mathrm{~m}$.

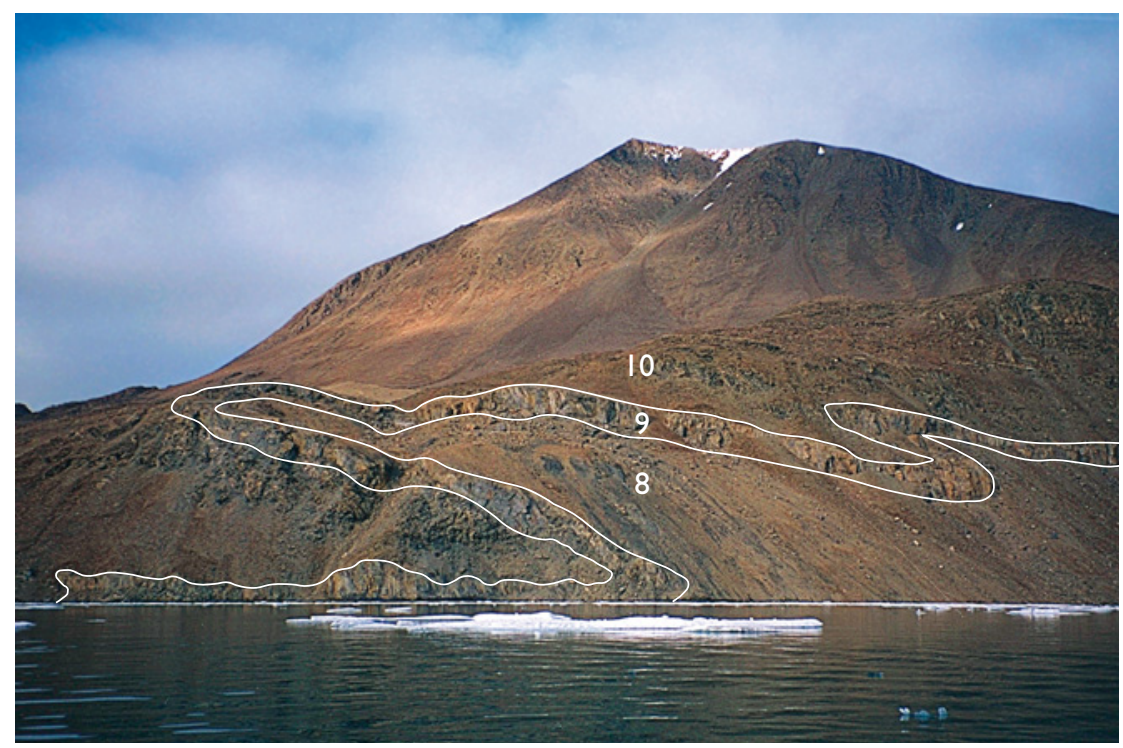

\section{Regional geological mapping}

A decade later the Frederick E. Hyde Fjord region was revisited in the period 1978-1980 during helicoptersupported regional systematic mapping by the Geological Survey of Greenland (Henriksen \& Higgins 1991). The Citronen Fjord area is included on the 1:500 000 Peary Land map sheet (Bengaard \& Henriksen 1986a; Henriksen 1992). Hurst \& Surlyk (1982) visited the area during their regional study of the Silurian turbidites (Peary Land Group). They referred all strata at Citronen Fjord to the Merqujôq Formation (the basal part of the Peary Land Group) illustrating the geology by an aerial photograph (Hurst \& Surlyk 1982, fig. 58; Hurst 1984). This interpretation was shown on the geological map in Friderichsen et al. (1982).

Hurst \& Surlyk (1982) defined the carbonate breccio-conglomerates interbedded with mudstones and siltstone turbidites, conspicuous in the western part of the area along Citronen Fjord and west of Esrum Elv, as the Citronens Fjord Member of the Merqujôq Formation. The type section (Hurst \& Surlyk 1982, section 33; Fig. 3) contains two main intervals of conglomeratic rocks, with the lower and thickest interval containing a conglomerate unit about $80 \mathrm{~m}$ thick. The resedimented limestone conglomerate beds, interpreted as base-ofslope debris flows by Hurst \& Surlyk (1982), correspond to Units 9 and 11 of this paper (see Fig. 7).

The Citronen Fjord area is part of the region mapped by Pedersen $(1979,1980,1982)$. In mapping the carbonate conglomerate units as markers in a fairly uniform sedimentary succession (Units 9 and 11 of this paper),
Pedersen (1982) in an unpublished thesis recognized the existence of argillaceous rocks stratigraphically lower than the Citronens Fjord Member referring the strata to the Ordovician Amundsen Land Group. The map in Pedersen (1982), showing a narrow, NW-SE striking inlier of Amundsen Land Group (Nordpasset Formation) on the east side of Citronen Fjord following 'East Elv', that continues on the western side of the fjord at its mouth, is the outcrop pattern adopted on recent maps of the area, e.g. Bengaard \& Henriksen (1986a, b).

Sulphide mineralization within limestone conglomerates south of Citronen Fjord in association with fault splays of the NW-SE-trending Trolle Land Fault Zone was also reported by Pedersen (1982; Fig. 3). Fracture-filling copper-zinc mineralization was noted with quartz-calcite veining; the main mineral assemblage being pyrite, sphalerite, chalcopyrite and trace galena. The mineralization is stratabound and it has an epigenetic appearance (Pedersen 1982). Laboratory investigations on Pedersen's samples during a mineral assessment programme were reported by Lind (1993) who concluded that the sulphides were probably deposited in the permeable conglomerates from hydrothermal solutions rising through the fault zone.

The gossans and mineralization noted in 1979 are on the western side of 'Citronen Elv', actually within sight of the massive sulphides discovered more than a decade later by Platinova A/S on the eastern side of the river (i.e. Discovery area on Fig. 3). Drilling has proved that the showings observed in 1979 are part of the narrow zone of post-sedimentary mineralization 
(Zone XX) occurring in the Middle and Hangingwall debris flows (Units 7 and 9; see section 'Stratigraphy of the Citronen Fjord area', p. 17).

\section{Commercial exploration strategy}

Although mineral exploration in the High Arctic has been naturally hampered by its remoteness and climatic conditions, there have been operative mines in the Canadian Arctic Islands for many years and one, the Polaris zinc-lead mine, is within the Franklinian Basin (Fig. 2). The nearest mines to northern Greenland are zinc-lead operations; Nanisivik in the Borden Basin of northern Baffin Island has been in production since 1976 and the Polaris mine farther north has been operative since 1982. These two underground operations are presently the world's most northerly metal mines. The geological provinces housing these two mineral deposits - Proterozoic in the case of Nanisivik, Palaeozoic in the case of Polaris - have direct geological counterparts on the opposite side of the Baffin Bay - Nares Strait seaway, in northern Greenland (Dawes 1994; Fig. 2).

A glance at a metallogenic map of this part of the Arctic, for example that given by Gibbon (1991), shows several prospective areas for economic minerals in the Canadian Arctic Islands. One of these is the Franklinian Basin that stretches for $2500 \mathrm{~km}$ from the Beaufort Sea to the Wandel Sea (Fig. 2). Present geological knowledge defines that the two major provinces of this basin - a southern or south-eastern platform and shelf and a northern deep-water trough - existed throughout Lower Palaeozoic time and that these provinces stretch across the Arctic Islands and continue into North Greenland (Dawes \& Kerr 1982; Trettin 1991).

In the 1970s and 1980s several base metal discoveries were made in the Arctic Islands within the Palaeozoic rocks of the Franklinian Basin, with a main target being zinc-lead mineralization within carbonates and in the off-shelf shale facies. Apart from Polaris, one discovery to the east was made by Great Plains Development Ltd. in Judge Daly Promontory, just $30 \mathrm{~km}$ from the Greenland coast, within Lower Palaeozoic shelf rocks bordering the deep-water sediments of the Hazen Formation (Fig. 2; see Gibbon 1991). These carbonate shelf formations and the argillaceous Hazen Formation have direct stratigraphical counterparts to the east in western North Greenland and yet that region in the early 1980s had only been subjected to sporadic commercial investigations.

\section{Discovery of the massive sulphides}

In 1992 Platinova A/S participated in a joint venture program with Nanisivik Mines Ltd. to explore for base metals in the Franklinian Basin, in western North Greenland (Hall Land - Freuchen Land region, see Figs 2, 22). The primary focus of this work was an assessment of the deep-water clastic sediments of the Amundsen Land Group, the stratigraphic equivalent of the Hazen Formation of Arctic Canada. This group occurs in the Nyeboe Land - Freuchen Land region as a narrow east-west striking belt over a distance of about 300 kilometres (Higgins et al. 1992). Numerous, minor occurrences of zinc and lead sulphides in various settings were found throughout the belt during helicopter reconnaissance. Although none of these occurrences had apparent economic potential, it was obvious that the Amundsen Land Group is highly prospective and that a similar evaluation of the eastern portion of the belt was warranted. In Peary Land to the east, exposures of Amundsen Land Group sediments are largely confined to the lands bordering Frederick E. Hyde Fjord where there are discontinuous outcrops over a distance of about 125 km (Friderichsen et al. 1982; Bengaard \& Henriksen 1986a; Higgins et al. 1991a, b).

Thus, after the initial investigations in western North Greenland in 1992, Platinova A/S continued the study into the following year with a prospecting programme in the Frederick E. Hyde Fjord area. Field work was based on the low-cost logistics of skidoo transport using the fjord-ice in spring and early summer as main access through the region. This program began in May and had as one of its primary objectives the investigation of the reported gossans and sulphide occurrences in the Citronen Fjord area that had been observed in 1969 and 1979. Massive, outcropping sulphides were encountered on the first day of exploration at Citronen Fjord in the inland gossan area now termed the Discovery area (Figs 1,3,19). The discovery was so promising that a full-scale exploration programme that included drilling was organized and executed the same summer (MINEX 1993).

The Discovery area is close, but not obviously related, to the fracture-controlled mineralization sampled by the Geological Survey of Greenland in 1979 and it is about eight kilometres south-east of the outcropping sulphides first observed and sampled in 1969 on the south shore of Frederick E. Hyde Fjord (Fig. 3). Our exploration suggests that sulphide mineralization may be continuous between these two areas outlining a major NW-trending mineralization zone. 
The geological, geophysical and drilling work started in 1993 by Platinova A/S has continued each year to include summer 1997. Until then, 143 exploration holes have been completed, totalling $32400 \mathrm{~m}$.

\section{Geophysical exploration}

After the initial discovery of surface outcrops, the evaluation of the Citronen Fjord deposit has been strongly guided by geophysical techniques that were introduced immediately in 1993. Gravity and some time-domain electromagnetic surveys have formed the basis of the geophysical work that was mainly conducted in the summer periods of 1993-1995.

Bouger gravity maps generated from readings at 50 $\mathrm{m}$ stations on lines at $100 \mathrm{~m}$ apart have proved to be a reliable indicator of the distribution of sub-surface sulphides. Electromagnetic surveys have shown strong responses from the mineralization but barren sulphide units and graphitic host rocks also give conductive responses that are not of economic interest.

Gravity measurements respond to the presence of excess mass and have indicated the presence of thick sections of pyrite but the technique cannot specifically indicate areas of zinc or lead enrichment. However, this has not proven to be a serious limitation, as evaluation of gravity anomalies by drilling is a far more expedient means of locating base metal mineralization than by 'blind' drilling on the basis of geological extrapolation alone.

Gravity data have been corrected for elevation, and later terrain corrections were applied to compensate for the rough terrain and the influence of adjacent mountains and fjords. The terrain corrections did not significantly change the position of the gravity anomalies in the main Citronen Fjord valley which were drilled prior to their application.

\section{Regional geology}

Citronen Fjord is situated near the eastern end of the Franklinian Basin just north of the facies boundary between the southern carbonate platform and shelf and, a northern deep-water trough (Fig. 2). The basin was deformed in Devonian-Carboniferous time giving rise to a belt of tectonism and metamorphism that now occupies the northern coast of Greenland facing the Arctic Ocean (North Greenland Fold Belt); an orogenic belt that in broad terms coincides with the deep-water trough. The study area around Citronen Fjord lies at the southern margin of the North Greenland Fold Belt that is characterized by southerly-facing folds and thrust faults. Thus, the host strata to the main sulphide mineralization are folded, deep-water Ordovician argillaceous rocks with interbedded carbonate debris flows, derived from the nearby carbonate platform. The overlying Silurian clastic strata form the hinterland of Citronen Fjord (Figs 1, 4, 5).

The most dominant feature of the Franklinian Basin throughout Lower Palaeozoic time was an abrupt facies transition from shallow-water, primarily carbonate sedi- mentation in the south, to deep-water, dominantly fine clastic sedimentation in the north (Higgins et al. 1991a, b: Surlyk 1991). This pattern was established in late Precambrian to early Cambrian time with the initial subsidence of the basin. From early Cambrian to early Silurian time the geographical position of the facies front appears to have been relatively stable. Several widely separated exposures in western North Greenland of this facies front are represented by rocks of late Middle Ordovician to Early Silurian age. The most spectacular exposures are in the fjord walls of Navarana Fjord, between Freuchen Land and Lauge Koch Land (see Fig. 22); a fjord that has given its name to this palaeo-topographic feature, viz. the Navarana Fjord Escarpment (originally named the Navarana Fjord Fault, e.g. Hurst \& Surlyk 1984, fig. 5; also called the Navarana Fjord Lineament, e.g. Higgins et al. 1991a; Soper \& Higgins 1991).

This escarpment initially had a relief of over $1 \mathrm{~km}$ and was so steep that no sediments were deposited on the slope between the shelf and the trough. The in- 


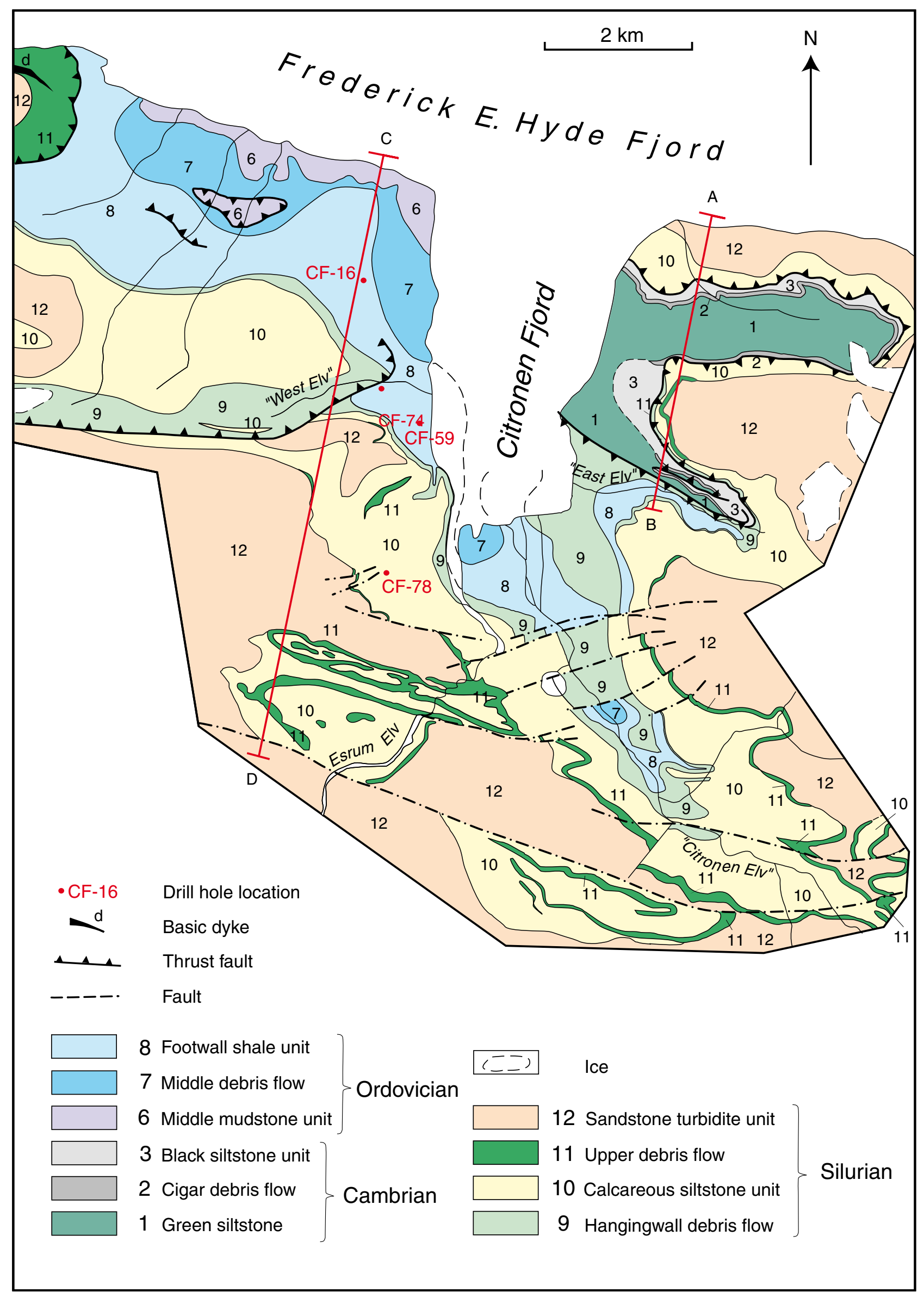


ferred projection of this carbonate escarpment to the east locates this southern boundary of the basin about $5 \mathrm{~km}$ to the south of the outcropping sulphides in the Discovery area (Escher \& Larsen 1987; Higgins et al. 1991a, b; Surlyk 1991; Surlyk \& Ineson 1992).

The mudstones, siltstones, fine-grained sandstones and carbonate debris flows that were deposited regionally in the trough throughout most of the Ordovician and into the Early Silurian have been assigned to three groups - the Vølvedal and Amundsen Land Groups and the lowest part of the Peary Land Group (Friderichsen et al. 1982; Higgins et al. 1992). Sandstone turbidite deposition in the trough began in late Llandoverian time (middle Early Silurian) in response to the onset of the Caledonian Orogeny in the east (Håkansson \& Pedersen 1982; Hurst \& Surlyk 1982). By the beginning of Wenlockian time (late Early Silurian) these sediments had buried the Navarana Fjord Escarpment. Filling of the trough by the sandstone turbidites caused the outer margin of the platform to subside and then fail, and the carbonates were transgressed by shales of the Wulff Land Formation (Håkansson \& Pedersen 1982; Hurst \& Surlyk 1982).

Within the Citronen Fjord map area, the Silurian Peary Land Group comprises Merqujôq Formation sandstone turbidites and calcareous siltstones, with the strata containing carbonate debris flows designated the Citronens Fjord Member (Hurst \& Surlyk 1982; Fig. 7). The most recent maps suggest that the nearest exposures of the overlying shales of the Wulff Land Formation are $30 \mathrm{~km}$ to the west of Citronen Fjord (Bengaard \& Henriksen 1986a, b).

\section{North}

South

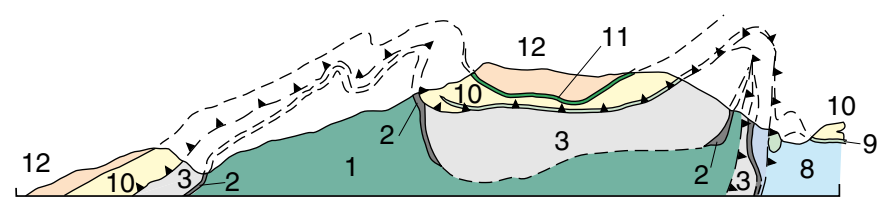

A

B

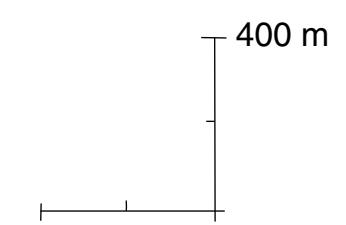

$800 \mathrm{~m}$

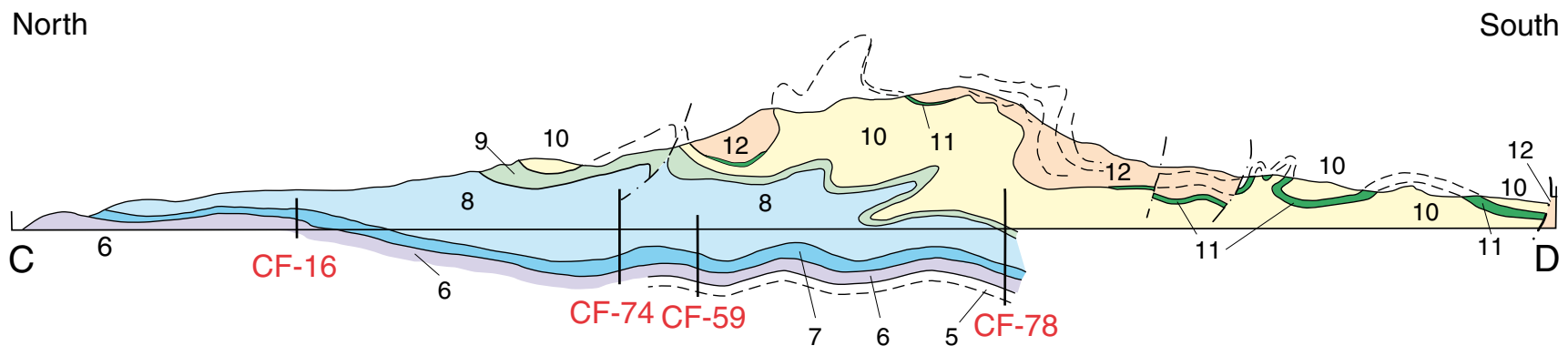

Fig. 6. Two geological cross-sections trending N-S show the structures at the east side (A-B) and west side (C-D) of Citronen Fjord. Eleven lithostratigraphic mapping units are indicated and the locations of drill holes supporting the construction of the profiles are given. Unit 4 was reached by the two most southerly holes. For location and legend, see Fig. 5.

Fig. 5. Simplified geological map of the Citronen Fjord area. Ordovician Units 4 and 5 are not shown since they are only known from drill cores. Unit 5 is shown on the cross-sections given in Fig. 6. The locations of these cross-sections A-B and C-D are indicated. 


\section{Geological map of the Citronen Fjord area}

\section{Cambrian-Silurian succession}

A geological map of the Citronen Fjord area featuring Cambrian, Ordovician and Silurian sediments is presented here as Figure 5. Based on field observations and drill-core data the succession has been subdivided into twelve lithostratigraphical units that are informally named and numbered consecutively, from oldest to youngest as Units 1 to 12 (see section 'Stratigraphy of the Citronen Fjord area' below). However, parts of the area have an appreciable cover of surficial deposits and two units ( 4 and 5), consistently present in drill cores, are not known from surface exposures. Hence, on the map only ten units are shown, with the stratal interval of Units 4 and 5 omitted. It is stressed that no stratigraphical hiatus is implied within the Ordovician sequence. Two cross-sections showing all but one (Unit 4) of the lithostratigraphic mapping units are given in Figure 6.

The area west of Citronen Fjord is characterized by the occurrence of large-scale recumbent fold structures and an associated east-west striking thrust fault (see section 'Structural elements in the Citronen Fjord area', p. 34). The recognition and mapping of geological units within the succession of predominantly sandstone turbidites and calcareous siltstones, are also hampered by the obvious intermixture of these rock types, both due to local facies changes and to folding on different scales. As marked on the geological map (Fig. 5), the northern projection of this east-west-striking thrust fault is uncertain.

The main part of the sequence forms a well-exposed, conformable stratigraphic pile stretching from the upper part of the Upper Ordovician Amundsen Land Group to the Silurian Peary Land Group (Fig. 7). The oldest rocks mapped, siltstones, conglomerate and cherts of Lower Cambrian age, outcrop on the eastern side of Citronen Fjord (referred here to the Buen Formation, see discussion in section 'Cambrian', p. 22 and Fig. 1). They are succeeded by Silurian calcareous siltstones and sandstone turbidites along what is interpreted to be a tectonic boundary rather than a stratigraphic unconformity. Some details of this contact are given below.

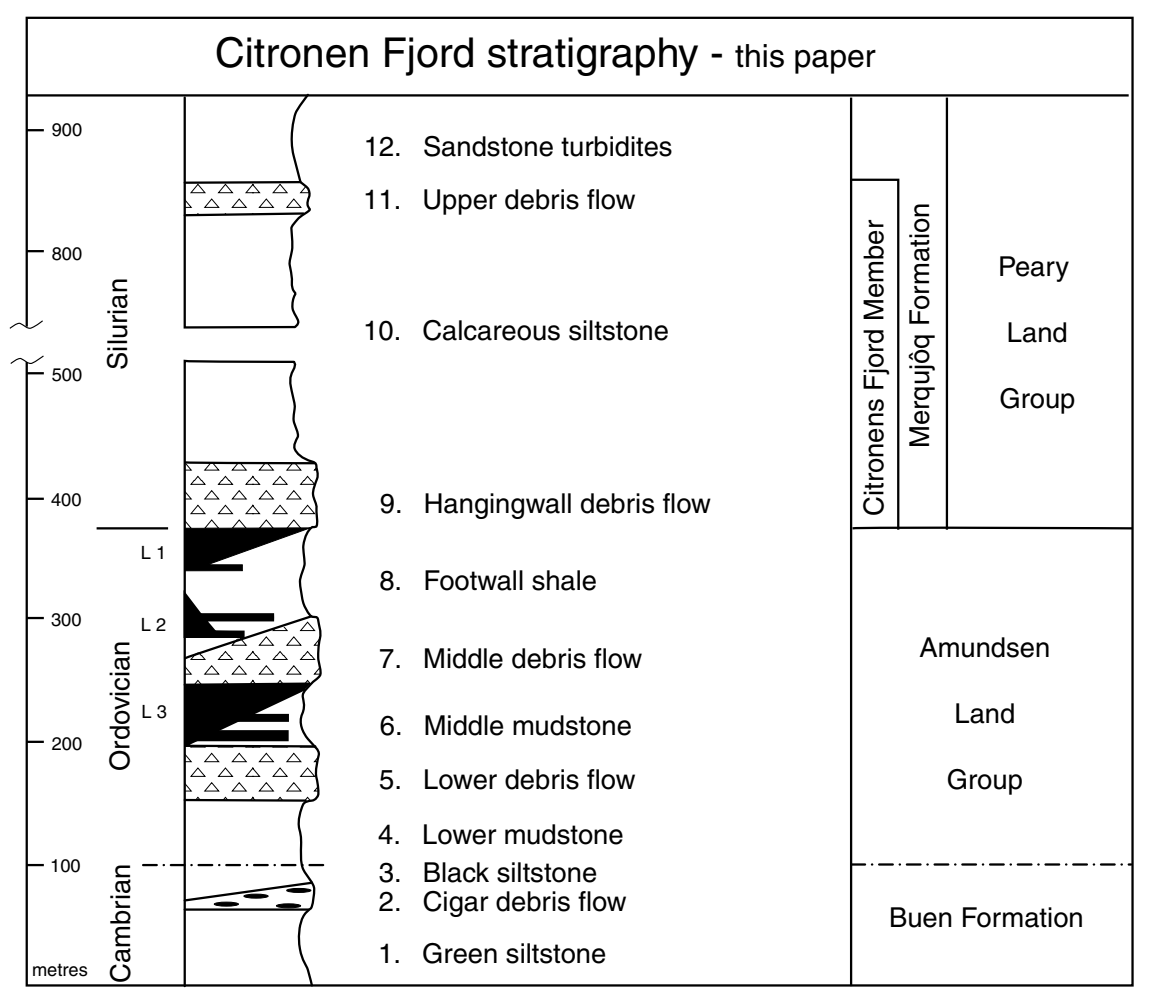

Fig. 7. Generalized stratigraphic section for the Citronen Fjord area showing the twelve informally-named units recognized in this paper, their correlation with the formally defined lithostratigraphy, and the three levels of massive sulphide mineralization (L1, L2 and L3). The geometric characteristics of the sulphide sheets within their respective host rock units is schematically shown by the shape of the black areas. The contact between the Cambrian and overlying succession is shown as tectonic. 


\section{Cambrian-Silurian contact}

In the cliff exposures both along the northern side of the valley 'East Elv' and on the eastern coast of Citronen Fjord (see Fig. 1), a variably rusty-weathering carbonate conglomerate occurs at the poorly exposed contact between Cambrian and Silurian strata. This is interpreted as a deformed stratigraphic equivalent of the Hangingwall debris flow (Unit 9). The matrix of this conglomerate is locally siliceous and individual clasts are commonly elongated and cigar-shaped and in many respects the conglomerate simulates the conglomerates of Unit 2 (the Cigar debris flow of Cambrian age, see Figs 7, 8).

However, the general chararacteristics of this deformed conglomerate favour a genetic relationship with the actual contact zone which is thus interpreted as a regional low-angle thrust fault. Whatever the precise geometry of this dislocation, it appears from regional comparisons that it represents the absence of an appreciable thickness of Cambro-Ordovician strata. This presumably includes the entire Vølvedal Group (if deposited in this part of the basin) and the entire Amundsen Land Group. The outcrop of Cambrian strata in the north-eastern part of the map area is limited to the south by a steeply-inclined NW-SE-trending thrust fault (Fig. 5).

\section{Basic dyke}

Basic dykes of several directions cut the Lower Palaeozoic strata of Johannes V. Jensen Land and the Frederick E. Hyde Fjord region (Soper et al. 1982; Henriksen 1992). Some N- to NW-trending dykes are shown in Figure 22. These dykes are regarded as late Phanerozoic (Cretaceous-Tertiary) in age and may reflect extensional events during Late Cretaceous rifting and the formation of the Eurasia basin to the east (cf. Surlyk 1991).

One NW-trending, fine- to medium-grained dolerite dyke is exposed along the south shore of Frederick E. Hyde Fjord just west of Citronen Fjord and shown in the north-western corner of the location and geological maps (Figs 3, 5). It is exposed within a very thick limestone conglomerate and at the contact with overlying and partly intercalated sandstone turbidite beds that are referred to Units 11 and 12 (Upper debris flow and Sandstone turbidites, see Fig. 7). The stratigraphic block of thick debris flows and sandstone turbidites in which the dyke occurs is underlain by black mudstones and siltstones that are referred to Unit 8 (Footwall shale). The major break thus indicated between these two successions is inferred to be a low-lying thrust fault (Fig. 5). The contact between the dyke and this thrust fault is not exposed.

\section{Stratigraphy of the Citronen Fjord area}

On the basis of field observations and drill core logging, the main characteristics of the twelve lithostratigraphic units recognized are summarized here in chronostratigraphic order. The stratigraphic contacts between the units are conformable unless otherwise stated. A schematic stratigraphic section, which also shows the positions of the three main levels of mineralization, is shown in Figure 7.

\section{Buen Formation}

The three oldest units of the succession mapped at Citronen Fjord are referred to the Buen Formation of Cambrian age (Jepsen 1971; see discussion under
'Lithostratigraphic correlation', p. 22). A discontinuous carbonate debris flow unit separates darker coloured, upper and lower siltstone units (Fig. 1).

\section{Unit 1: Green siltstone}

The dominant lithology of this basal unit is fine-grained, thick-bedded to massive, greenish grey siltstone. The unit shows thickness variation that may be in part tectonic. Thus, in the north near Frederick E. Hyde Fjord a vertical thickness of at least $300 \mathrm{~m}$ is present while the unit appears to thin to less than $100 \mathrm{~m}$ of true thickness to the south along Citronen Fjord. However, the base of the unit is not exposed, neither has it been 


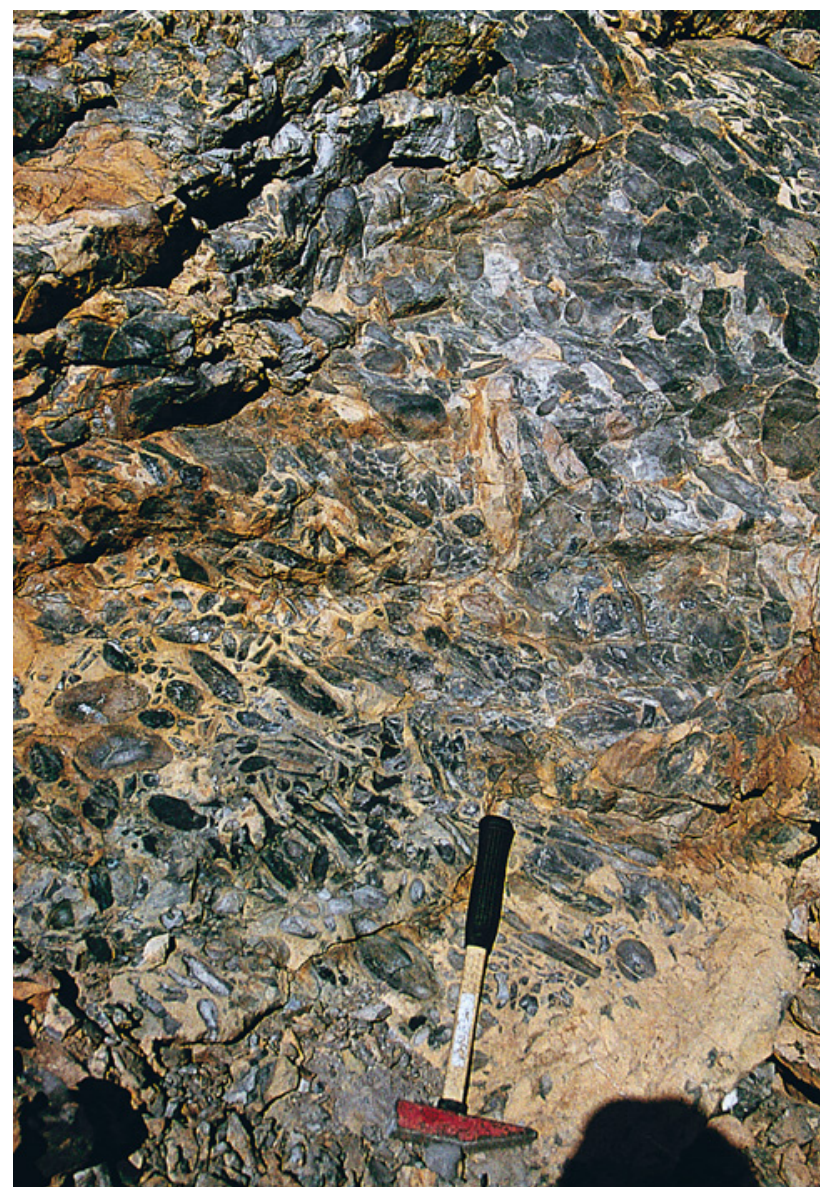

Fig. 8. Cigar debris flow (Unit 2) of presumed Early Cambrian age showing rounded, elongated clasts of dark carbonate in a quartzitic matrix. This is the oldest debris flow unit in the Citronen Fjord area. The hammer is $40 \mathrm{~cm}$ long. 'East Elv'; for location, see Fig. 3.

reached by drilling, and thus true thicknesses are unknown. The age of the unit is uncertain since no fossils have been collected.

\section{Unit 2: Cigar debris flow}

This, the oldest debris flow mapped, is a pale weathering unit composed of elongated clasts of carbonate and calcareous mudstone in quartzitic matrix; hence the informal name Cigar debris flow (Fig. 8). The unit, which in places has a basal metre-thick layer of massive dolomite, is discontinuous, varying in thickness up to $15 \mathrm{~m}$. Where the debris flow is absent (or not exposed), the stratigraphic division of the siltstones occurring on either side into Units 1 and 3 is difficult and subject to interpretation. No fossils are known.

\section{Unit 3: Black siltstone}

This upper argillaceous unit is composed of black, rather monotonous, carbonaceous, planar-laminated and thin-bedded siltstone, which is locally phyllitic. Disseminated pyrite is common. Exposures of siltstones interbedded with black and dark grey cherts are common at the surface in the far north-eastern corner of the map area. The unit has a maximum thickness of $100 \mathrm{~m}$ and it thins markedly along the inferred thrust fault contact with the overlying Silurian (Units 9 and 10) where it is locally absent (Figs 5, 6).

The siltstones include a poorly exposed trilobite-rich horizon from which Olenellus svalbardensis Kielan, known from elsewhere in Peary Land, has been identified (J. Bergström, personal communication 1997; Blaker \& Peel 1997) indicating an Early Cambrian age (Fig. 9).

\section{Amundsen Land Group}

In the Citronen Fjord area, the Amundsen Land Group (Friderichsen et al. 1982) is composed of dark, recessive, argillaceous strata with intermittent pale weathering, resistant, resedimented carbonate debris flows. Five mapping units are recognized with the two argillaceous units hosting the Citronen Fjord massive sulphides.

\section{Unit 4: Lower mudstone}

The Lower mudstone is dominated by dark grey interbedded dolomitic siltstone and graphitic mudstone, with common intercalations of arenite. The unit is similar to Unit 6 but lenses and 'eyes' of chert formed by the in situ replacement of siltstone and mudstone are common. Minor disseminated pyrite is present. No surface exposures are known. This unit is the lowermost unit intersected in drill holes and thus true thickness is unknown.

\section{Unit 5: Lower debris flow}

Like Unit 4, stratigraphically below it, this unit is not known from surface exposures. It is a clast-supported carbonate debris, strongly dolomitized and occasionally silicified. Minor pyrite is present in the matrix, especially in the upper part of the unit. Clast size indi- 
Fig. 9. Olenellus svalbardensis Kielan, 1960. Dark siltstone of Unit 3 (Buen Formation); magnification: $\mathbf{a}, \times 1.2$; b, $\times 1.5$. Depository: Geological Museum, Copenhagen; a, MGUH 24.554; b, MGUH 24.555. Photos: Peter Moors.
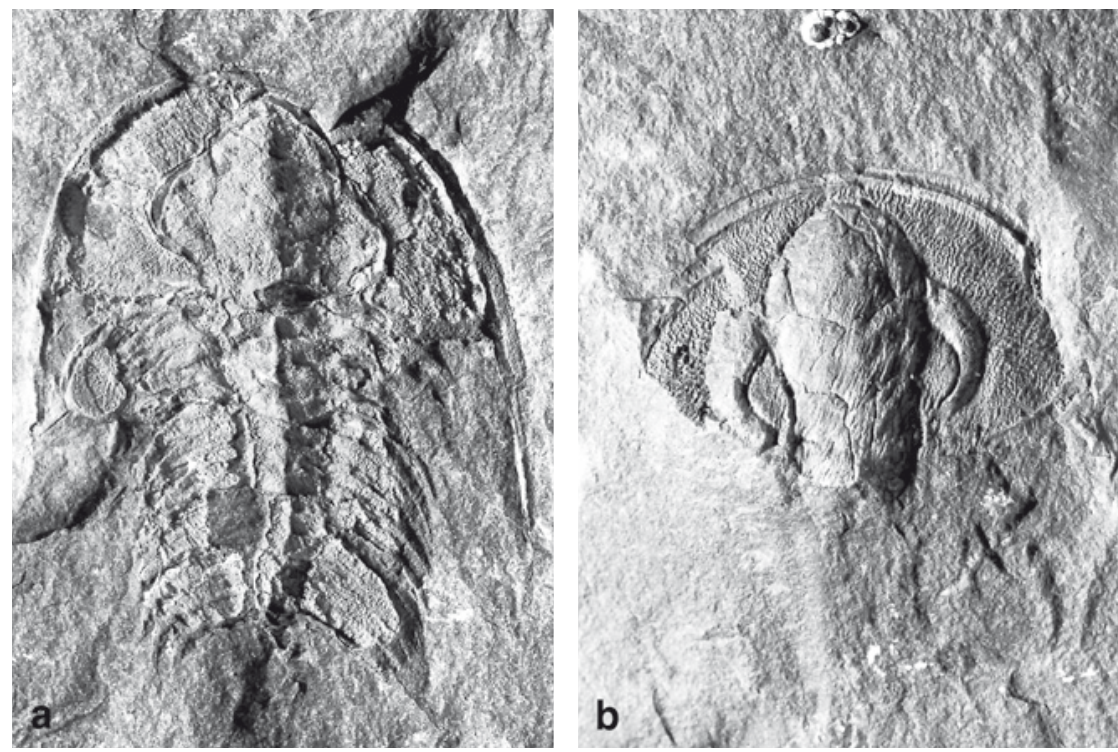

cates sorting. The average thickness of the unit based on drill hole data is $45 \mathrm{~m}$.

\section{Unit 6: Middle mudstone}

This is a dark unit composed of a rhythmic layering of black graphitic, dolomitic and/or calcitic mudstone and dark grey siltstone, variously calcareous arenite, minor carbonate debris flows with fine- to medium-grained massive pyrite beds. Soft-sediment deformation and dehydration textures are characteristic features. The upper part of the unit is commonly brecciated due to depositional erosion by the overlying debris flow (Unit 7). The Middle mudstone unit varies from about $15 \mathrm{~m}$ to $85 \mathrm{~m}$; the average thickness from drill cores is $50 \mathrm{~m}$. This unit is the host rock of Level 3 sulphide mineralization (Fig. 7).

\section{Unit 7: Middle debris flow}

This is a matrix- and clast-supported calcareous and dolomitic limestone conglomerate unit showing sorted clast size especially in the uppermost part. Preferred orientation of clasts (imbricate structure) occurs locally. The clasts are generally fossiliferous with crinoids, reef corals and occasionally brachiopods being the main forms; the matrix is argillaceous. The conglomerate is locally altered by a penetrative process of dolomitization with associated gradational replacement of matrix and clasts by pyrite and occasionally base metal sul- phides (sphalerite and minor galena; see section 'Postsedimentary mineralization', p. 30). The lower part of the debris flow generally contains angular clasts of laminated massive sulphides, i.e. ripped up from the underlying Level 3 sulphide sheet by depositional erosion.

The thickness of this unit varies between a minimum of $2 \mathrm{~m}$ and a maximum of $104 \mathrm{~m}$ and is typically inversely proportional to the amount of the underlying massive sulphides (Level 3). The average thickness measured from drill holes is $50 \mathrm{~m}$.

The Middle debris flow shows lateral variations in lithology. Thus in the southern outcrops along 'Citronen Elv' and immediately west of the Discovery area, and also near the west shore of Citronen Fjord, the largely monomictic conglomerate shows rusty weathering and is strongly pyritic. Towards Frederick E. Hyde Fjord, it abruptly changes character into a strongly pyritic, polymictic debris flow containing abundant, huge ('housesize') boulders of dolomite with common intercalations and enclosures of siliceous arenite, black mudstones and massive, fine-grained pyrite. Drill cores and rock exposures in the West gossan area indicate abundant and extensive slump and tectonic breccias, resulting in a stratigraphic-tectonic pattern not seen elsewhere in the Citronen Fjord area.

These rock types occur in the vicinity of the regional Harder Fjord Fault Zone (Fig. 3), that supposedly has been active during long periods. The highly disturbed character of the rock formations in this northern area could well be due to this major dislocation (see section 'Structural geology', pp. 32-33). 


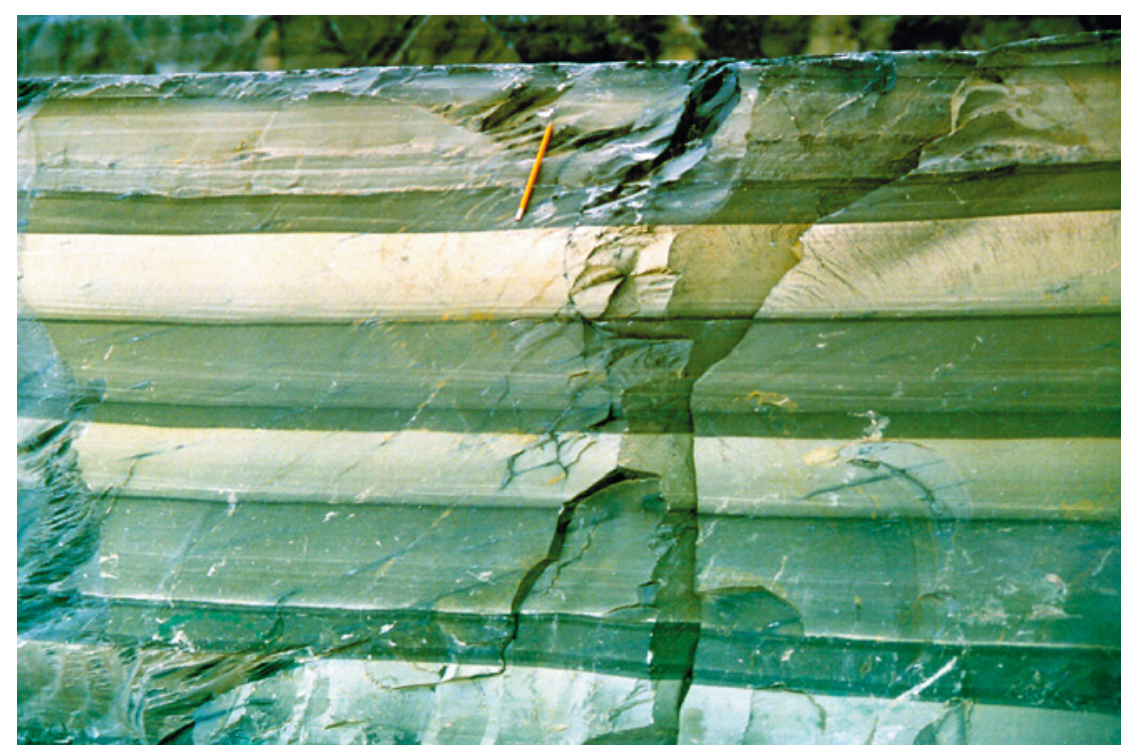

Fig. 10. 'Tiger striped' calcareous siltstone of Unit 10. The pen is $14 \mathrm{~cm}$ long. Esrum Elv, near the type locality of the Citronens Fjord Member; for location, see Fig. 3.

\section{Unit 8: Footwall shale}

This unit received its informal name 'Footwall shale' in 1993 after the discovery of outcropping massive sulphides in the inland gossan area, south-east of Citronen Fjord. Here, the unit forms the footwall of the stratiform (Level 1) sulphide sheet while the hangingwall is formed by an extensive carbonate debris flow, which for that reason was field-dubbed 'Hangingwall debris flow' (Unit 9; see Figs 5, 7).

The main lithology of the unit is black graphitic mudstone with dark grey, weakly calcareous siltstone. Intercalations of calcarenite and thin carbonate debris flows are common. Soft sediment deformation structures occur but are not characteristic. The unit is very similar to the calcareous siltstone of Unit 10 both in drill core appearance and outcrop, except that sedimentary features like ripple marks and cross-laminations are lacking. Scattered and disseminated pyrite occur throughout. The unit thickens rapidly to the north-west of Esrum Elv where there is an increase in the number of intercalated limestone debris flows. The drill-core thickness of the unit varies between 45 and about 100 $\mathrm{m}$ with an average of $55 \mathrm{~m}$.

This unit hosts the upper levels of sulphide mineralization, viz. Levels 1 and 2 (Fig. 7).

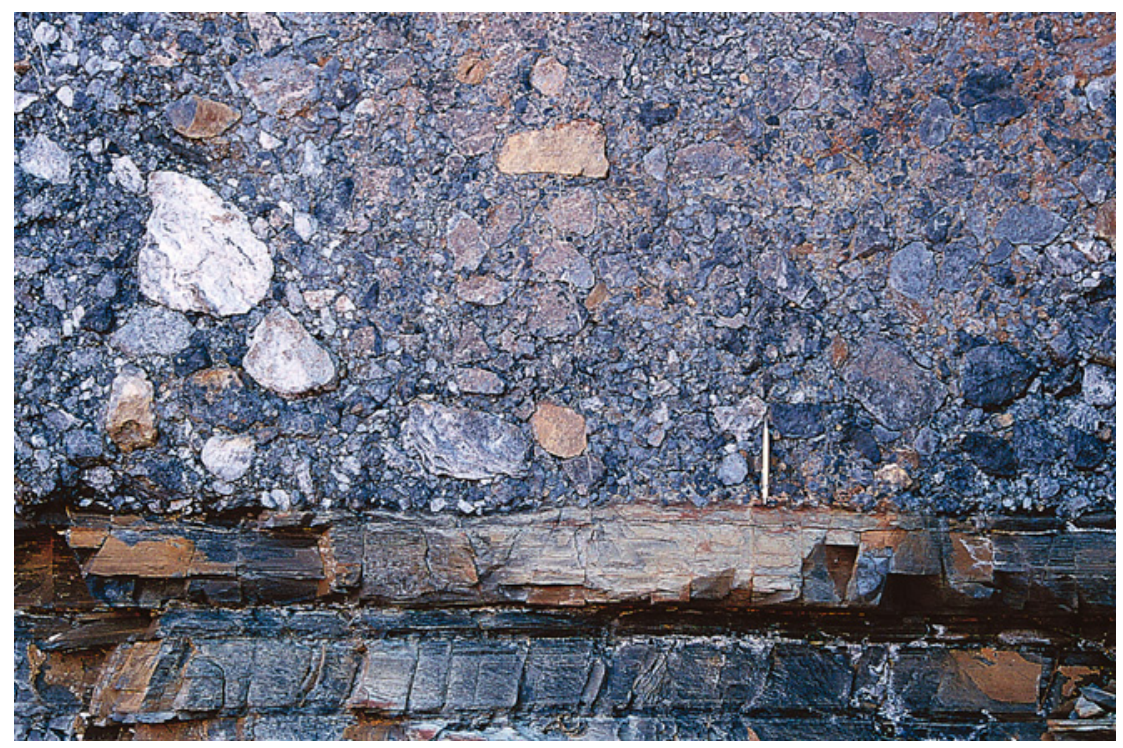

Fig. 11. Sharp contact between the Upper debris flow (Unit 11) and the underlying calcareous siltstones of Unit 10 showing slight encroachment of the siltstone by the debris flow. The pen is $14 \mathrm{~cm}$ long. Esrum Elv, near the type locality of the Citronens Fjord Member; for location, see Fig. 3. 
Fig. 12. Strongly-developed bottom structures, interpreted as flute casts, in upright folded sandstone turbidite beds of Unit 12 - the basal part of the Merqujôq Formation of Hurst \& Surlyk (1982). Hammer in centre as scale. South of Esrum area; for location, see Fig. 3.

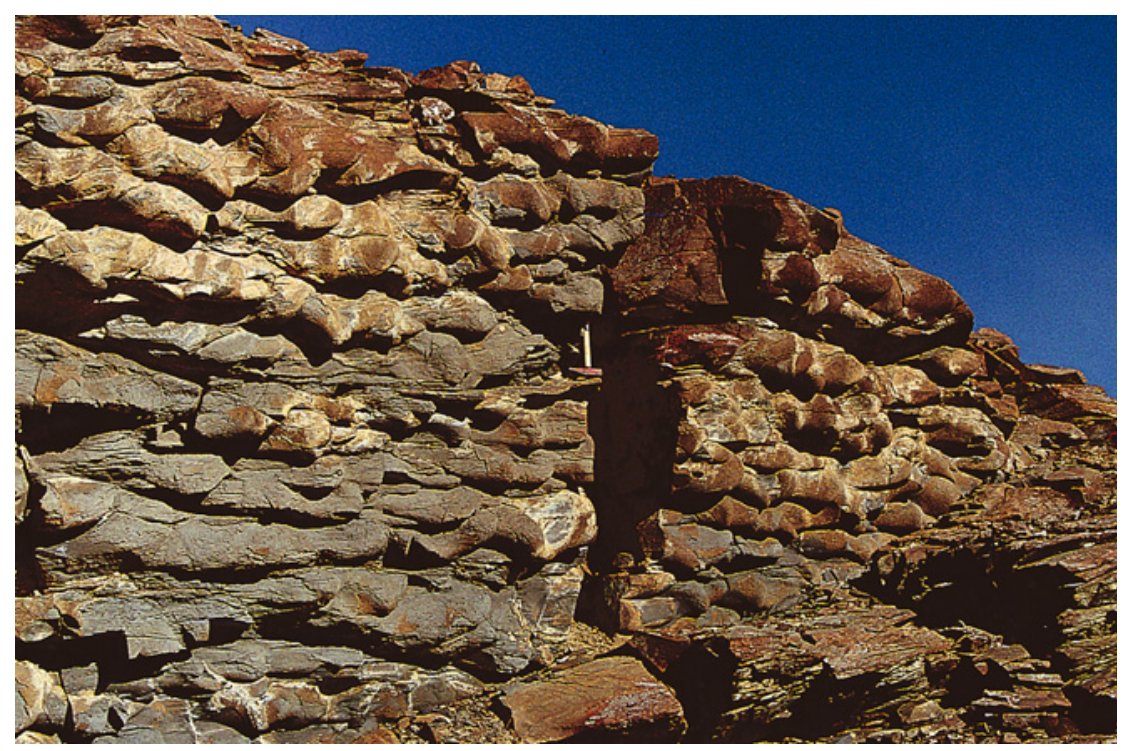

\section{Peary Land Group (Merqujôq Formation)}

The Peary Land Group (Hurst 1980) represents the uppermost strata of the Lower Palaeozoic succession in the Citronen Fjord area, being overlain by Quaternary and Recent deposits. Four mapping units are recognized, all of which are referred to the Merqujôq Formation of Hurst \& Surlyk (1982).

\section{Unit 9: Hangingwall debris flow}

This is a clast-supported limestone conglomerate; the clasts are size sorted, especially in the upper part, and they occasionally show a preferred orientation. The carbonate clasts are fossiliferous with crinoids and reef corals common; a coral-crinoid-brachiopod fauna is regarded by Bjerreskov \& Poulsen (1973) to be of Llandovery age. The conglomerate generally has a brown to rusty appearance (Fig. 4). Pyrite is a common constituent within the matrix; in places pyrite occupies the entire matrix, with occasional traces of sphalerite and galena. The thickness of the unit varies from a few metres to $90 \mathrm{~m}$; the average thickness from drill cores is about $55 \mathrm{~m}$. In general, the unit has a sharp lower contact with the argillaceous rocks of Unit 8.

The Hangingwall debris flow unit equates with the lower and thicker of the two carbonate conglomerate units in the Citronens Fjord Member of Hurst \& Surlyk (1982; Fig. 4) that has a thickness of about $80 \mathrm{~m}$ at the type locality.

\section{Unit 10: Calcareous siltstone}

This unit is generally of rather monotonous lithology composed of dark grey, thin-bedded calcareous siltstone and muddy carbonate turbidites. Some types show a discrete banding of darker and paler silt beds (Fig. 10). A common, well-preserved sedimentary feature is cross-lamination (starved ripples). Graptolites, common at certain intervals, indicate a Late Llandovery age for Unit 10 that corresponds to the age of the Citronens Fjord Member established by Hurst \& Surlyk (1982).

The main graptolites identified in our samples are Monograptus turriculatus, Monograptus ex. gr. exiguus, Monograptus cf. becki, Monograptus sp. cf. contortus, Pristiograptus sp., Streptograptus pseudoruncinatus, and Rastrites carnicus n. ssp., indicative of the M.turriculatus Zone of early Telychian age (M. Bjerreskov, personal communication 1993). A single graptolite, Monograptus aff. Monograptus anguinuus, from $30 \mathrm{~m}$ below the top of the Citronens Fjord Member - presumably within Unit 10 of this paper - is reported by Hurst \& Surlyk (1982) and said to be indicative of the Monograptus spiralis Zone.

Scattered pyrite is common, but no massive sulphides have been observed. The unit is hardly distinguishable from Unit 8 (Footwall shale) in both outcrop and drill core, and, although the unit forms a discrete stratigraphic interval between the units of debris flow (Units 9 and 11), calcareous siltstones indistinguishable from Unit 10 lithology, interdigitate with the turbidites of the overlying, and uppermost unit of the succes- 
sion, viz. Unit 12. The estimated thickness of Unit 10 is between 200 and $450 \mathrm{~m}$.

\section{Unit 11: Upper debris flow}

This unit is a clast-supported limestone conglomerate in which clast size varies from centimetre to a couple of metres (see Fig. 26). In general, the rock is poorly sorted; vague preferred orientation of clasts is locally seen. The clasts are fossiliferous with crinoids and reef corals the most common forms. The matrix is argillaceous but it becomes increasingly sandy in northern exposures where the unit thins out and gradually changes into a matrix-supported conglomerate. The Upper debris flow, which is characterized by sharp upper and lower boundaries (Fig. 11), has an average thickness of about $20 \mathrm{~m}$.

The Upper debris flow corresponds with the thin limestone conglomerate beds that occur in the upper- most part of the type section of the Citronens Fjord Member of Hurst \& Surlyk (1982, section 33; location in Fig. 3).

\section{Unit 12: Sandstone turbidites}

This, the uppermost unit of the exposed succession the map area, is a reddish brown weathering, fine-grained turbiditic sandstone with common intercalations of carbonate and quartz-chert debris flows, and abundant calcareous siltstone. Sedimentary features such as graded bedding, cross-bedding, load casts, and flute marks are common (Fig. 12).

The sandstone turbidites interfinger with the calcareous siltstones of Unit 10 and they are limited upwards by the present erosion surface and surficial deposits. Our estimate of the preserved thickness of Unit 12 in the Citronen Fjord area is about $700 \mathrm{~m}$ but a greater thickness may occur to the south.

\section{Lithostratigraphic correlation}

In the section above, the twelve informal lithostratigraphic units recognized in the Citronen Fjord area, are described under three formally-named rock units, viz. the Cambrian Buen Formation, the Ordovician Amundsen Land Group and the Silurian Peary Land Group. In addition, the early Silurian part of the succession is correlated at formation level (Merqujôq Formation) while one member - the Citronens Fjord Member - that has its type section at Citronen Fjord (see Fig. 3), is readily applicable to this study (Fig. 7).

However, formal lithostratigraphic subdivision of the Cambro-Ordovician trough sediments in North Greenland has not been made and the formations mentioned in the literature and included on published maps of the Frederick E. Hyde Fjord area have not been formally described (Bengaard \& Henriksen 1986a, b; Pedersen \& Henriksen 1986; Higgins et al. 1991a; Henriksen 1992).

A summary of the lithostratigraphy of the Frederick E. Hyde Fjord area, taken from published sources, is given in Figure 13 but the stratal limits of the seven formations of the Vølvedal and Amundsen Land Groups, and their spatial distribution, remain unpublished. The correlation of the lower eight units mapped by us at Citronen Fjord to named units in the literature is not obviously apparent and therefore in this paper no formal correlation is attempted. However, some comments on the correlation of the informal units with the regional lithostratigraphy are given below as an aid to further mapping and research.

\section{Cambrian}

Are the Cambrian strata recognized herein at Citronen Fjord representative of the Buen Formation or the Polkorridoren Group?

The Polkorridoren Group is a monotonous sequence at least $2 \mathrm{~km}$ thick of turbiditic sandstones, siltstones and mudstones with a type area to the north-west of Citronen Fjord in Johannes V. Jensen Land (see Fig. 22; Dawes \& Soper 1973; Friderichsen et al. 1982). The 
nearest exposures of this group have been mapped by Soper et al. (1980) immediately north of Citronen Fjord on the opposite side of Frederick E. Hyde Fjord, some $5 \mathrm{~km}$ distant. During our field work, Units 1, 2 and 3 were referred to the Buen Formation of Jepsen (1971) that is exposed to the east of Citronen Fjord in the Depotbugt - G. B. Schley Fjord area on the north-east side of the Trolle Land Fault Zone (Christie \& Ineson 1979; see Fig. 22). The formation has a wide distribution farther south in Peary Land, everywhere overlying the platform carbonates of the Portfjeld Formation (Henriksen 1992).

The Buen Formation (Jepsen 1971) is defined as a typical siliciclastic shelf facies that grades over the outer shelf and margin into the slope and trough sediments of the Polkorridoren Group (Higgins et al. 1991a). Although the Cambrian strata at Citronen Fjord are situated north of the early Cambrian shelf and therefore might invite direct correlation with the deep water sediments of the Polkorridoren Group in Johannes V. Jensen Land, we favour placing the oldest strata of the Citronen Fjord area (Units 1, 2 and 3) in the Buen Formation. This disposition is based on the following observations and considerations.

1. The Cigar debris flow (Unit 2), which intermittently occurs within the Lower Cambrian sequence, probably represents an early base-of-slope debris flow derived from, and closely associated with, the nearby platform.

2. Our reconnaissance mapping along the southern coast of Frederick E. Hyde Fjord towards Depotbugt has proved the regional extent of the early Cambrian strata, with the correlation to the tripartite sequence at Citronen Fjord being confirmed by lithology and occasional finds of olenellid trilobites in black shales. As previously described (see section 'Cambrian-Silurian contact', p. 17), at the contact with the overlying sandstone turbidites of the Merqujôq Formation, a highly tectonized limestone debris flow with strongly elongated pebbles confirms the tectonic relationship between the Cambrian and Silurian parts of the succession.

3. In the Depotbugt area, the Merqujôq Formation and underlying Cambrian strata are in direct contact with early Silurian laminated and banded shelf carbonates of the Odins Fjord and Ymers Gletscher Formations (Hurst 1984). A few kilometres farther east, carbonates belonging to the Cambrian Portfjeld For-
Frederick E. Hyde Fjord stratigraphy

\begin{tabular}{|c|c|}
\hline Nordkronen Formation & \\
\hline Lauge Koch Land Formation & \\
\hline Wulff Land Formation & \\
\hline Frejas Fjord Mbr & \\
\hline Citronens Fjord Mbr Formation & \\
\hline Sydgletscher Formation & \\
\hline Harder Fjord Formation & \multirow{4}{*}{$\begin{array}{c}\text { Amundsen } \\
\text { Land } \\
\text { Group }\end{array}$} \\
\hline Nordpasset Formation & \\
\hline Kap Mjølner Formation & \\
\hline Harebugt Formation & \\
\hline Nornegæst Formation & \multirow{3}{*}{$\begin{array}{l}\text { Vølvedal } \\
\text { Group }\end{array}$} \\
\hline Drengs Bræ Formation & \\
\hline Bøggild Fjord Formation & \\
\hline Frigg Fjord mudstone & \multirow{2}{*}{ 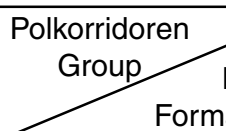 } \\
\hline Mapping units $a-f$ & \\
\hline
\end{tabular}

Fig. 13. General stratigraphic chart of the Lower Palaeozoic succession of the Frederick E. Hyde Fjord region compiled mainly from Higgins et al. (1991a), with some reference to Soper et al. (1980) and Henriksen (1992).

mation are overlain by dark clastic sediments of the Buen Formation (Christie \& Ineson 1979; Bengaard \& Henriksen 1986a, b; Henriksen 1992).

4. The Polkorridoren Group of Johannes V. Jensen Land is structurally separated from the Lower Palaeozoic sediments south of Frederick E. Hyde Fjord by a major and regional dislocation - the Harder Fjord Fault Zone. This fault zone may well have been active during the Lower Palaeozoic sedimentation (Soper \& Higgins 1987, 1991; see section 'Harder Fjord Fault Zone', p. 32).

We conclude that the Cambrian sediments exposed at Citronen Fjord and along the south side of Frederick E. Hyde Fjord to Depotbugt (Fig. 22), and referred herein to the Buen Formation, form a structural wedge tectonically separated from the Silurian succession by a low-angle thrust fault. To the north, this wedge is separated from the Cambrian deep-water sediments of 
the Polkorridoren Group by the Harder Fjord Fault Zone. This group is exposed over large areas of Johannes V. Jensen Land (Bengaard \& Henriksen 1986b; Henriksen 1992). The nearest exposures to Citronen Fjord have been mapped by Soper et al. (1980) immediately to the north on the opposite side of Frederick E. Hyde Fjord, some $5 \mathrm{~km}$ distant.

\section{Ordovician}

Two groups of deep-water trough sediments containing Ordovician strata have been formalized in Peary Land: a lower, Vølvedal Group that overlies the Polkorridoren Group, and the Amundsen Land Group that passes up into the Peary Land Group (Friderichsen et al. 1982). At Citronen Fjord, the Ordovician strata are in stratigraphic contact with overlying Silurian strata and, based on lithology and regional thickness considerations, we refer all the Ordovician strata at Citronen Fjord to the Amundsen Land Group.

The definition of the Amundsen Land Group by Friderichsen et al. (1982) was unfortunately not accompanied by the formal subdivision into formations. However, three (originally 'un-named') formations were identified, viz. "two mainly fine-grained formations" and "a southern resedimented conglomeratic formation" (Friderichsen et al. 1982, p. 15). These were named on the 1:500 000 Peary Land map sheet (Bengaard \& Henriksen 1986a) as a unit of resedimented carbonate conglomerate - the Kap Mjølner Formation - and two units of bedded chert, mudstone and siltstone - the Harebugt and Nordpasset Formations. Pedersen (1982; adopted in Lind 1993) referred all strata at Citronen Fjord identified at that time as Ordovician, to a single formation - the Nordpasset Formation.

However, a fourth formation is now recognized in Peary Land - the Harder Fjord Formation - representing the youngest strata of the group being overlain by the Peary Land Group (Higgins et al. 1991a). This formation, of black chert, mudstone, siltstone and thin-bedded silty turbidite, heralds the end of starved basin deposition in latest Ordovician to early Silurian times.

Published descriptions imply that the Harder Fjord Formation is present throughout southern Johannes V. Jensen Land; it has certainly been recognized to the south of Frederick E. Hyde Fjord in eastern Hans Egede Land (see Higgins et al. 1991a, fig. 2). The uppermost part of the Citronen Fjord succession composed of mudstone, siltstone and intercalations of turbidites and carbonate debris flows (Unit 8) that passes up into the
Peary Land Group is thus provisionally referred to the Harder Fjord Formation.

However, the precise correlation of the remaining part of the Ordovician to Silurian strata at Citronen Fjord to the tripartite division of Harebugt, Kap Mjølner and Nordpasset Formations is more debatable, although clearly the two major carbonate conglomerate units (Units 5 and 7) are candidates for correlation with the debris flow units that make up the Kap Mjølner Formation and that form prominent outcrops to the west in Amundsen Land (Pedersen \& Henriksen 1986).

We conclude that the Vølvedal Group does not occur in the Citronen Fjord area. The lower limit of the younger Amundsen Land Group (Fig. 13) at Citronen Fjord is unknown and the absence of the Vølvedal Group could be due to tectonism. However, in any attempts at regional correlation, it should be kept in mind that the apparent, rather restricted occurrence of massive sulphides in the Citronen Fjord area implies the existence of a sedimentary sub-basin, the boundaries of which probably were defined by syngenetic fault systems. Therefore, the Citronen Fjord stratigraphy could be of local development with the extension of specific lithological sequences limited to the size of the original sub-basin and without obvious correlational characteristics with time-equivalent rock units elsewhere in the region.

\section{Silurian}

The Silurian calcareous siltstones, sandstone turbidites and carbonate debris flows that form the major part of the exposed bedrock in the Citronen Fjord area, are correlated with the Merqujôq Formation of Hurst \& Surlyk (1982). As discussed in the lithostratigraphic descriptions, Units 9, 10 and 11 belong to the Citronens Fjord Member of Hurst \& Surlyk (1982), the type section of the member being in our study area (location on Fig. 3). This debris flow member marks the end of the massive sulphide deposition in the Citronen Fjord sub-basin.

It needs to be stressed that these Silurian strata (Units 9 to 11) are part of the 'hangingwall' sequence that overlies the late Ordovician 'ore-bearing' mudstones and siltstones with the intermediate carbonate debris flows (Units 6 to 8; Fig. 7). This interpretation and stratigraphic correlation differ from the published interpretation of Stemmerik et al. (1996) according to which all ore-bearing sediments are concentrated in the Silurian Citronens Fjord Member. 


\section{Citronen Fjord mineralization}

\section{Mineral assemblages and grades}

The stratabound sulphide mineralization at Citronen Fjord is comprised of massive and bedded pyrite that contains variable amounts of sphalerite and minor amounts of galena. Silver, barium and copper are present in very minor quantities. A preliminary estimate of the total tonnage of sulphides encompassed by the two ore-bearing argillaceous units - the Footwall shale (Unit 8) and the Middle mudstone units (Unit 6) - exceeds 350 million tons. This figure is calculated on the basis of the mean value for the cumulative thickness of sulphides intersected by each drill hole and on the apparent lateral continuity of the sulphides between the holes.

The sulphides are generally fine- to medium-grained; some are weakly-bedded and laminated, others lack sedimentary features. There is a variation in the textures from massive and semi-massive to the intermittent presence of dendritic-textured pyrite (Figs 14, 15); the net-like texture of Kragh et al. (1997). When best developed, this dendritic texture is a fern-like pattern of open spaces lined with pyrite framboids that locally are overgrown by euhedral pyrite crystals. The open spaces, representing up to 50 per cent of the rock volume, are filled by calcite or dolomite spar. This pattern can be seen to overprint or replace sedimentary textures within sulphides but in most instances no suggestions of primary textures remain.

Zinc and lead grades are characteristically less than 3 per cent zinc and less than 1 per cent lead within the massive and dendritic-textured pyrite. Sphalerite and minor galena appear to have been remobilized into open spaces and fractures as irregular, medium- to coarse-grained concentrations.

The bedded and laminated sulphides contain the greatest concentrations of lead and zinc. Bedded sulphides are characteristically fine grained, planar-laminated and thin-bedded (Fig. 16). Individual layers range in thickness from $1 \mathrm{~mm}$ to $1 \mathrm{~m}$, although decimetre thicknesses are most common and beds in excess of $30 \mathrm{~cm}$ are rare. Sedimentary structures such as graded bedding, cross-lamination and dewatering features have been observed (Kragh 1997; Kragh et al. 1997). With few exceptions, contacts with interbedded mudstone are sharp (Fig. 16) but they can often have an irregular form (Fig. 17).
Relationships suggesting that the sulphides grew within the mudstone sediment or at the water/sediment transition zone before consolidation confirm the synsedimentary character of sulphide genesis (Fig. 17).

Sulphides contain clay and silt as impurities and mudstone commonly contains up to 20 per cent disseminated pyrite.

Sphalerite has clearly been deposited contemporaneously with the enclosing pyrite and it commonly forms laminae but rarely beds. Normally it occurs interstitially to the pyrite framboids (Kragh 1997). Sphalerite is difficult to detect visually in pyrite when in

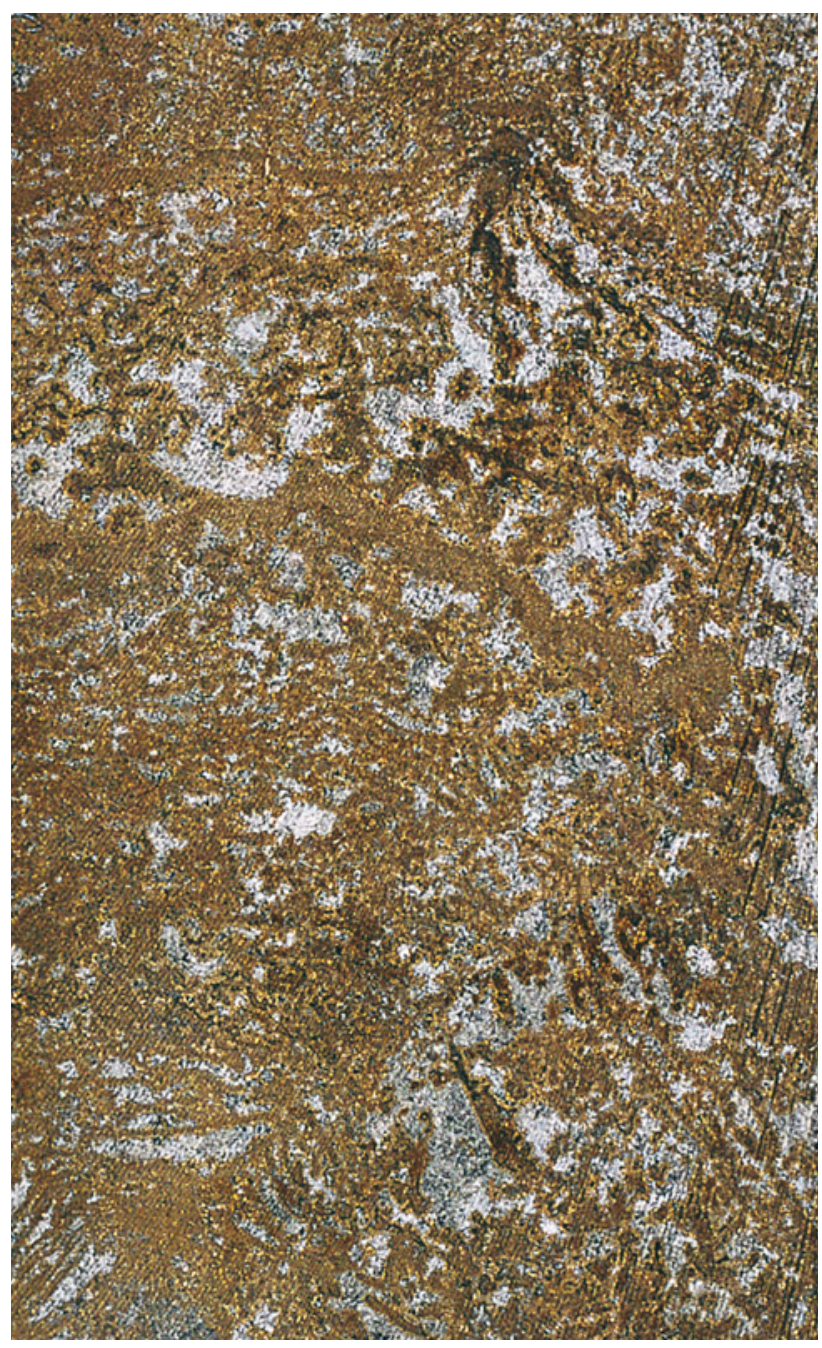

Fig. 14. Detail of typical dendritic-textured pyrite with calcite infilling. Platinova drill-core CF94-15 from Level 2 mineralization. The core is $3.6 \mathrm{~cm}$ across. Photo: Jakob Lautrup. 

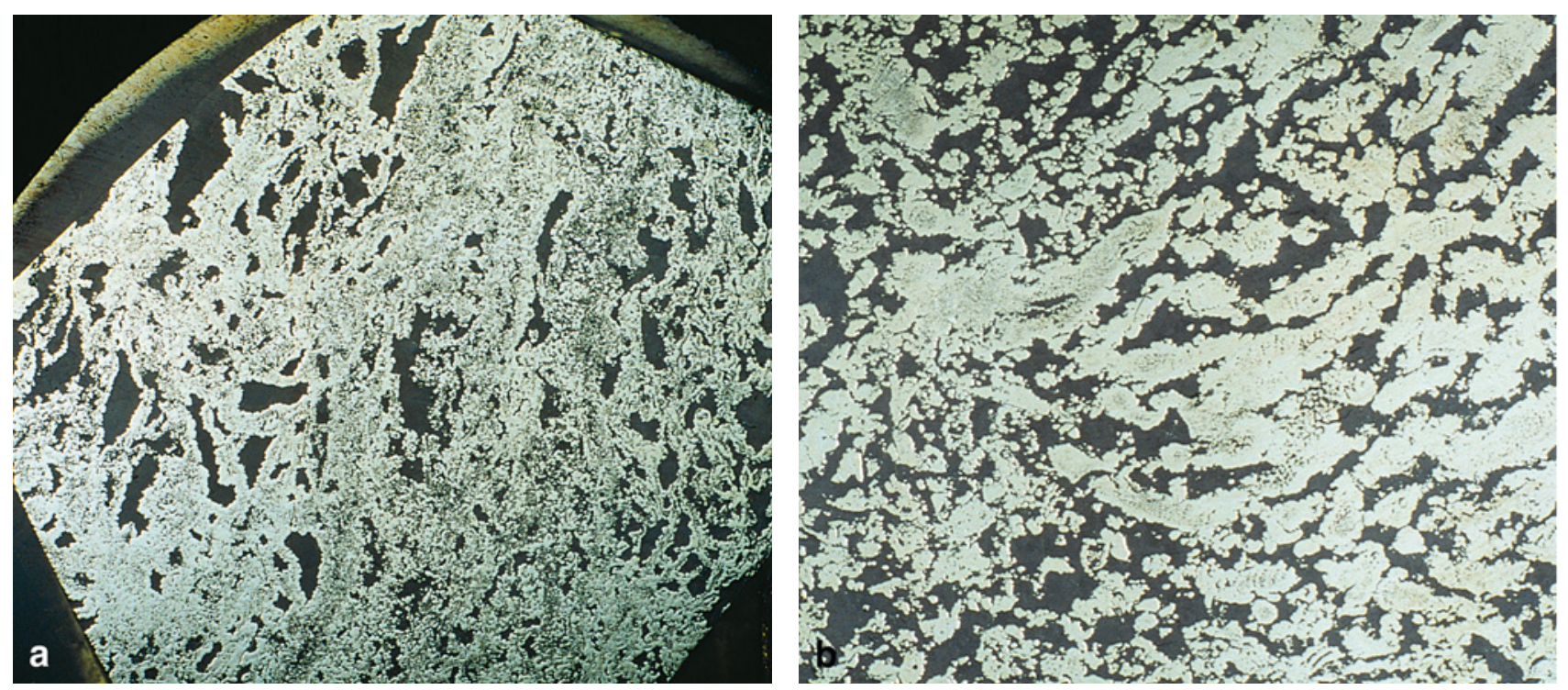

Fig. 15. Semi-massive dendritic sulphides (light) with sparry carbonate (dark). Reflected light, both samples about $2 \mathrm{~cm}$ across. a, GGU sample 410005 from Level 1 mineralization; also figured in Kragh (1996); b, Platinova drill-core CF94-15 in Level 2 mineralization. Photos: Jakob Lautrup.

quantities less than 10 per cent volume. The colour of the pyrite varies in proportion with the amount of zinc present. Thus where zinc content is in the range of 15-20 per cent, the pyrite has a brownish cast, and where zinc is in excess of 20 per cent, the pyrite is pinkish to reddish. The highest zinc content of a pyrite bed noted to date is 35 per cent.

No examples have been found of sedimentary sphalerite that has been deposited without accompanying pyrite but sedimentary pyrite without sphalerite is common. Many beds of pyrite have zinc contents of less than 1 per cent.

Pyrite, as microscopic spheres, occurs in all textures - massive, dendritic and bedded/laminated (Kragh 1997). Sphalerite and galena occur both as inclusions and, more commonly, as overgrowths on the pyrite spheres.

\section{Main levels of massive sulphide mineralization}

In the Discovery, Beach and Esrum areas, three main sulphide levels occur within a $200 \mathrm{~m}$ thick stratigraphic interval (Figs 3, 7). In the fourth mineralized area shown in Figure 3 - the West gossan area - one level of mineralization is delimited although disseminated suphides with slightly enhanced $\mathrm{Zn}$ values occur at various overlying stratigraphic levels.

\section{Discovery, Beach and Esrum areas}

The tripartite sulphide system that characterizes the Citronen Fjord area has been traced uninterruptedly by geophysics and drilling over a strike length of more than $5 \mathrm{~km}$ and a width of up to $500 \mathrm{~m}$. The gross strike of this trend is about $145^{\circ}$ azimuth. The individual sulphide sheets, hosted in argillaceous strata, are from uppermost to lowermost, termed Levels 1, 2 and 3, and they are spatially associated with three extensive limestone conglomerate units (Fig. 7).

\section{Sulphide Levels 1 and 2}

Levels 1 and 2 occur both within the Footwall shale (Unit 8) at slightly variable positions in relation to the Hangingwall debris flow (Unit 9) and underlying Middle debris flow (Unit 7, Fig. 7). In part of the Discovery area, the Hangingwall debris flow immediately overlies Level 1 sulphides, but elsewhere the upper sulphide sheet is separated from this debris flow by a siltstone of variable thickness. The division into two main upper sulphide levels is not always applicable in the Discovery area, since most of the Footwall shale is taken up by massive sulphides.

Level 2 sulphides in the Beach area are defined as occurring immediately above, or separated by a thin mudstone unit from the Middle debris flow (Unit 7) while Level 3 sulphides always occur immediately be- 


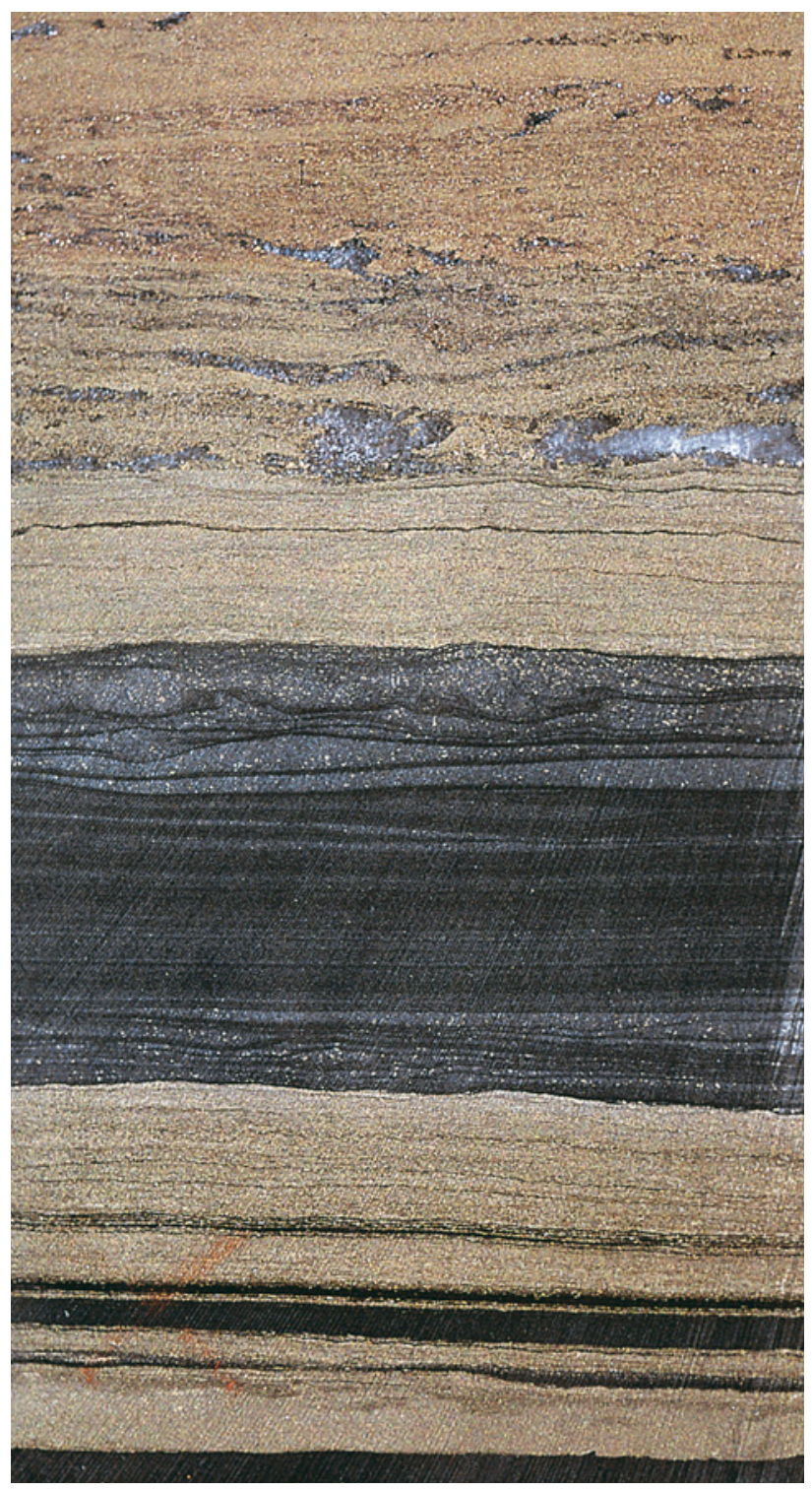

Fig. 16. Fine-grained laminated sulphides in black mudstone. The sulphide laminae consist of framboidal pyrite in a matrix of sphalerite and carbonate. Zn-content in the upper sulphide layer is $25-30 \%$ and in the lower layer $1-3 \%$. Platinova drill-core CF15 in Level 2 mineralization; figured in Kragh (1996). The core is $3.6 \mathrm{~cm}$ across. Photo: Jakob Lautrup.

low this debris flow in the Middle mudstone (Unit 6). There is evidence that the Middle debris flow has, in part, eroded the underlying Level 3 sulphides during deposition (Fig. 18).

Level 1 is the most southerly of the sulphide sheets and forms the massive sulphides exposed at surface (Discovery area shown in Fig. 19), as well as minor accumulations of pyrite laminae further to the north-west. This level of sulphides is exposed over a strike length of about $1200 \mathrm{~m}$ and a width of $300 \mathrm{~m}$.

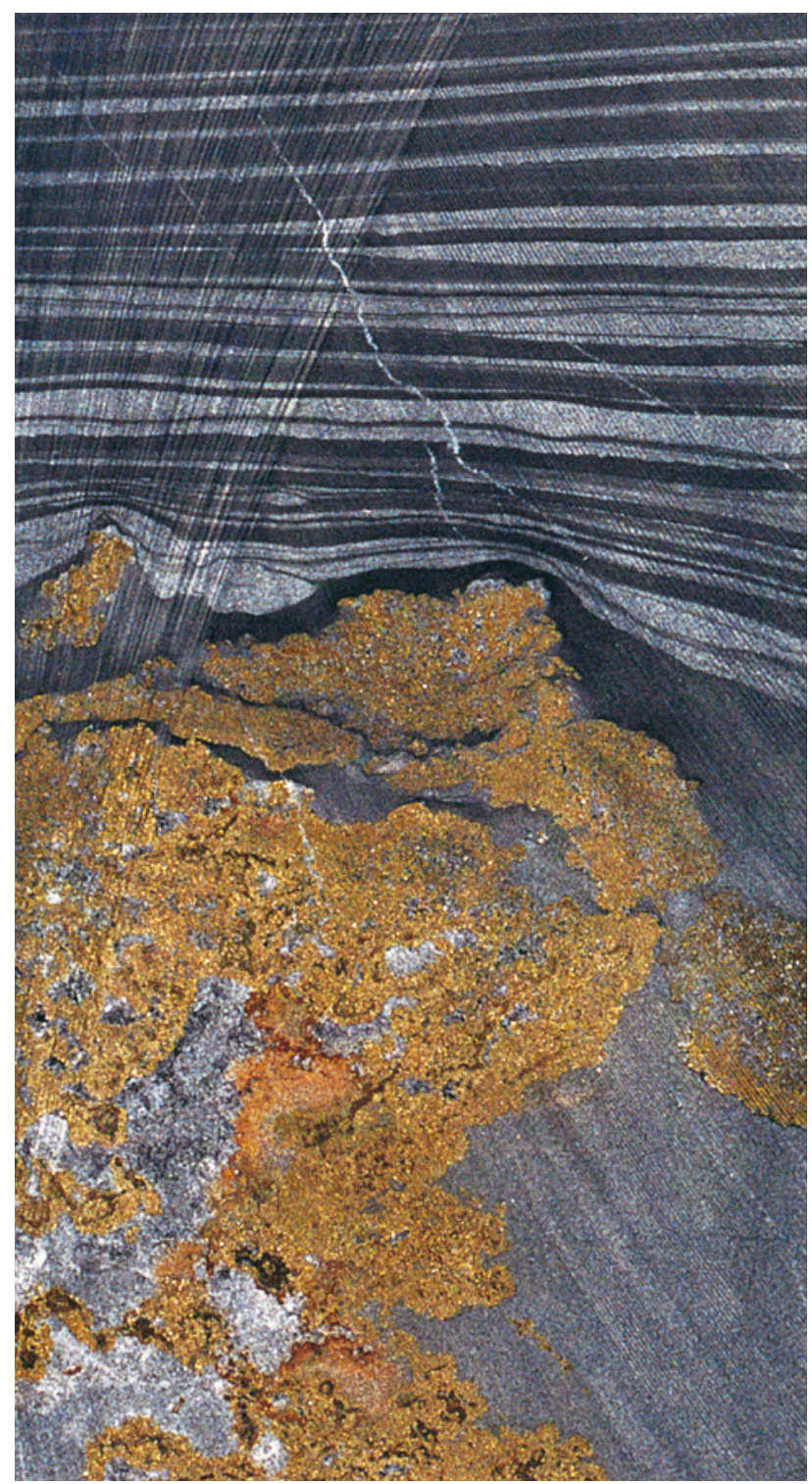

Fig. 17. Semi-massive sulphides draped by laminae of turbiditic calc-arenite and mudstone; evidence of syn-sedimentary genesis. Platinova drill-core CF94-15 in Level 3 mineralization; also figured in Kragh (1996). The core is $3.6 \mathrm{~cm}$ across. Photo: Jakob Lautrup.

Apart from local occurrences in the Discovery area, Level 2 mineralization is mainly restricted to two separate areas: it occurs sub-surface as a $2 \mathrm{~km}$ long and up to $500 \mathrm{~m}$ wide north-south striking belt in the Beach area (dipping $5-8^{\circ}$ towards the north) and as a $1 \mathrm{~km}$ long and $250 \mathrm{~m}$ wide, sub-parallel belt in the Esrum area (Fig. 3). In the intervening area, massive sulphides are absent in the Footwall shale.

In the Beach area, Level 2 is characterized as a series of massive to dendritic-textured sulphide mounds, 


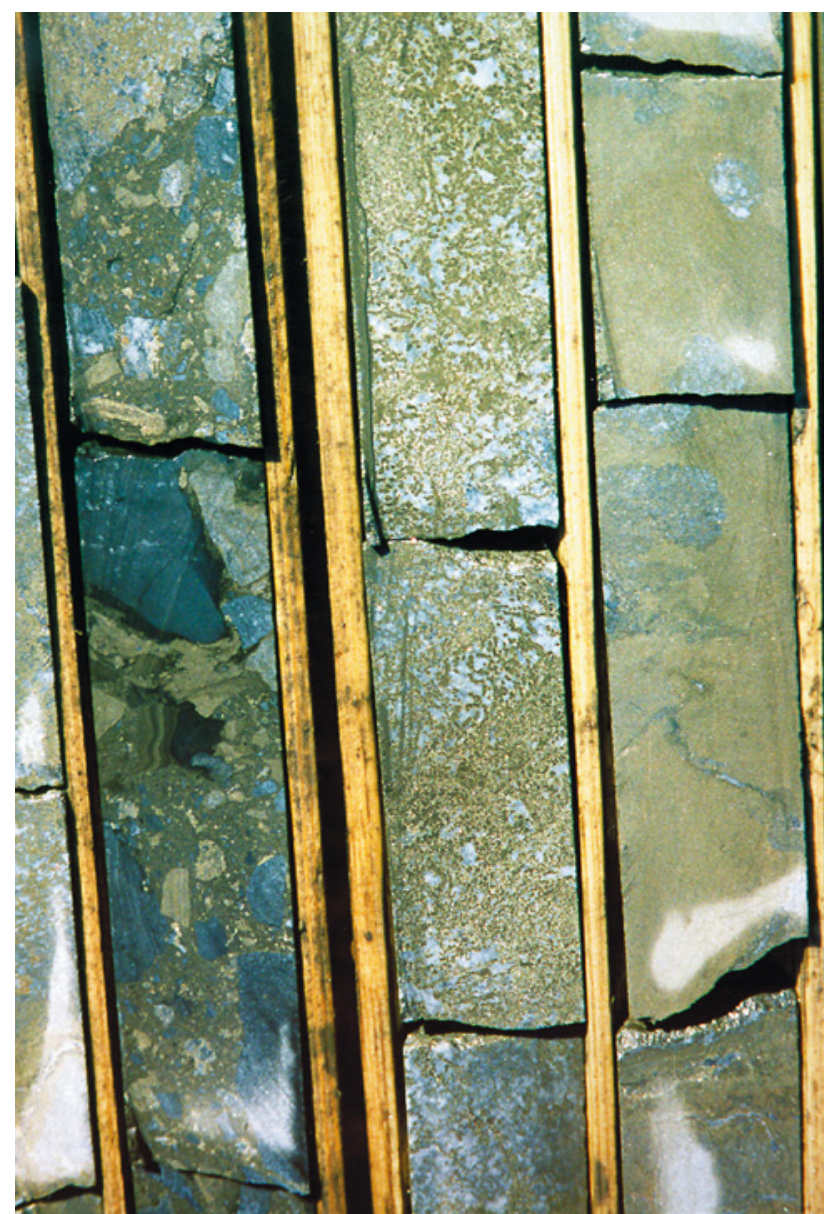

Fig. 18. Drill cores showing the transition from the Middle debris flow (Unit 7, left core) to the underlying Level 3 sulphides within the Middle mudstone unit (Unit 6; middle and right cores). Numerous fragments of finely laminated sulphides contained in carbonate debris indicates depositional erosion of the underlying sulphides by the debris flow. The middle core shows dendritic texture, while dense to vaguely slumped textures are seen in the more massive sulphides core on the right. Each core is $3.6 \mathrm{~cm}$ across.

up to $20 \mathrm{~m}$ thick surrounded by thin aprons of bedded sulphides 1-5 $\mathrm{m}$ thick. The highest combined zinc/lead grades occur in a 'channel' of mainly fine-grained, bedded sulphides $1 \mathrm{~km}$ long and some hundreds of metres wide that runs along the eastern rim of this Level 2 belt. The sulphide sheet characteristically consists of two prime layers which in most cases are separated by a less mineralized siltstone up to $10 \mathrm{~m}$ wide.
In the southern and western part of this channel, the highest zinc/lead values occur in the upper layer while in the north-eastern part the best combined grades come from the lower layer. Detailed exploration drilling at $100 \mathrm{~m}$ intervals within this Level 2 sulphide corridor has indicated a resource of 7 million tons, averaging 9 per cent zinc and 1 per cent lead by using a cut-off grade of 6 per cent zinc over $2 \mathrm{~m}$.

\section{Sulphide Level 3}

Level 3 comprises all sulphides within the Middle mudstone (Unit 6), between the overlying Middle Debris Flow and underlying Lower Debris Flow (Fig. 7). This level contains the greatest volume of sulphides with intercepts in excess of $10 \mathrm{~m}$ cumulative thickness encountered continuously for almost $3 \mathrm{~km}$ (strike $140-180^{\circ}$ ) in the Beach and Discovery areas and for at least $1.5 \mathrm{~km}$ (strike $160-180^{\circ}$ ) in the Esrum area (Fig. 3). There exists a series of mounds of massive and dendritic sulphide within these trends, the thickest of which reaches 57 $\mathrm{m}$. However, these sulphide accumulations have very low contents of base metals. Away from the mound centres, the dendritic texture becomes less conspicious with the increase of fine-grained and laminated, more zinc-rich sulphide bands with intercalated mudstone and calcarenite.

In contrast to the Footwall shale (Unit 8), the Middle mudstone (Unit 6 ) is also mineralized in the area between the two main Level 3 sulphide corridors and consequently, this lower sulphide sheet can be traced continuously from south-east of the Discovery area to the north-western end of the Esrum area.

\section{West gossan area}

The sulphide mineralization in the West gossan area (see Fig. 3) occurs in both the carbonate breccio-conglomerates and the intervening argillaceous and siliciclastic strata (Fig. 20). Reconnaissance drilling in the area has delimitated an extensive occurrence of extremely dense, massive pyrite at a stratigraphic level that is comparable to Level 3 of the Beach and Esrum areas. Slightly enhanced lead values, but only with zero

Fig. 19. Views of the Discovery area. Upper: view from the north showing two of the main gossans with exposures of massive sulphides at the base of the mountain slope immediately east of 'Citronen Elv'. The mountains in the background are also seen in the regional view of Fig. 1. Lower: outcrops of massive sulphides up-slope of the gossans shown in upper view. For map location of the Discovery area, see Fig. 3. 

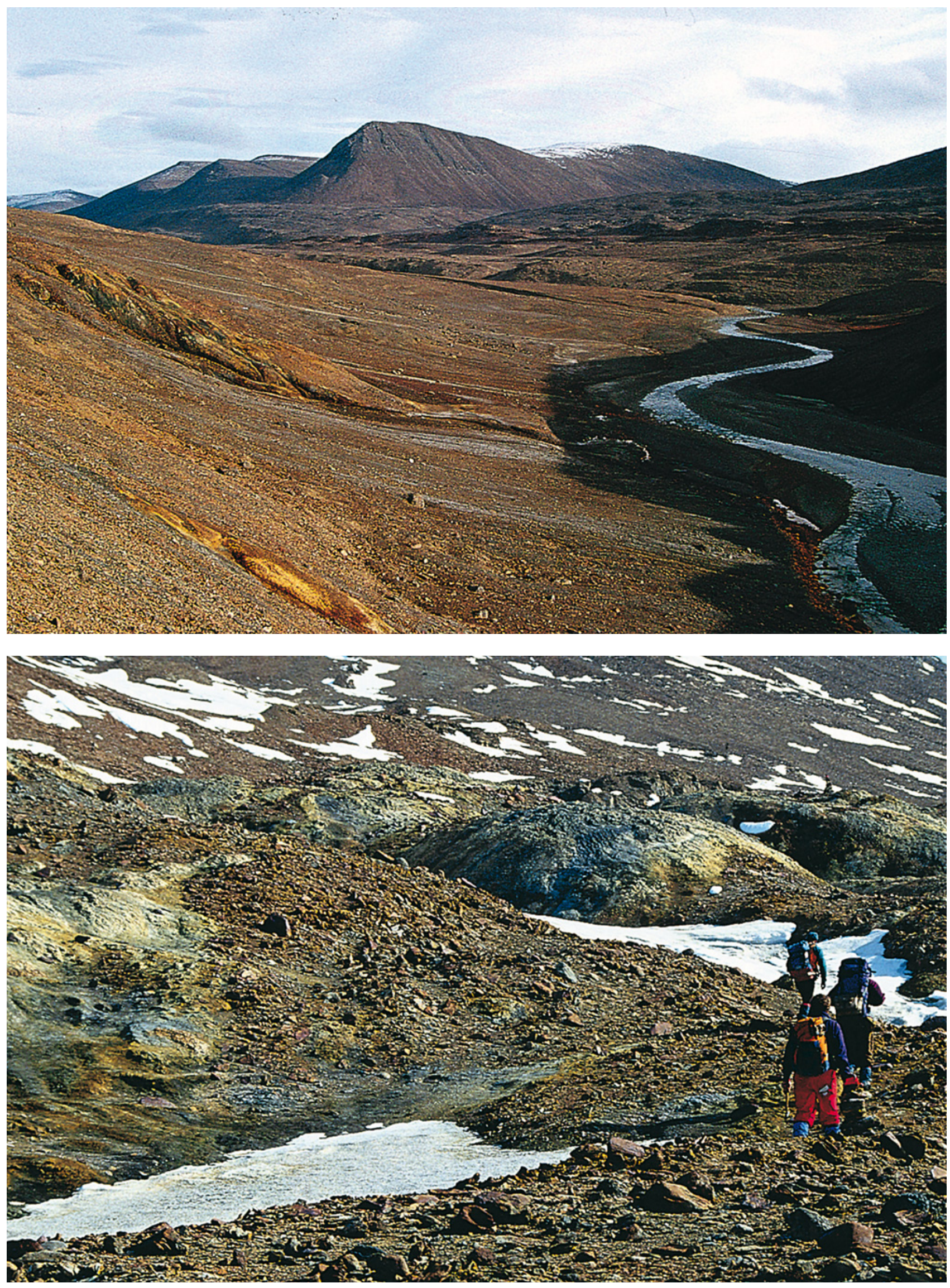


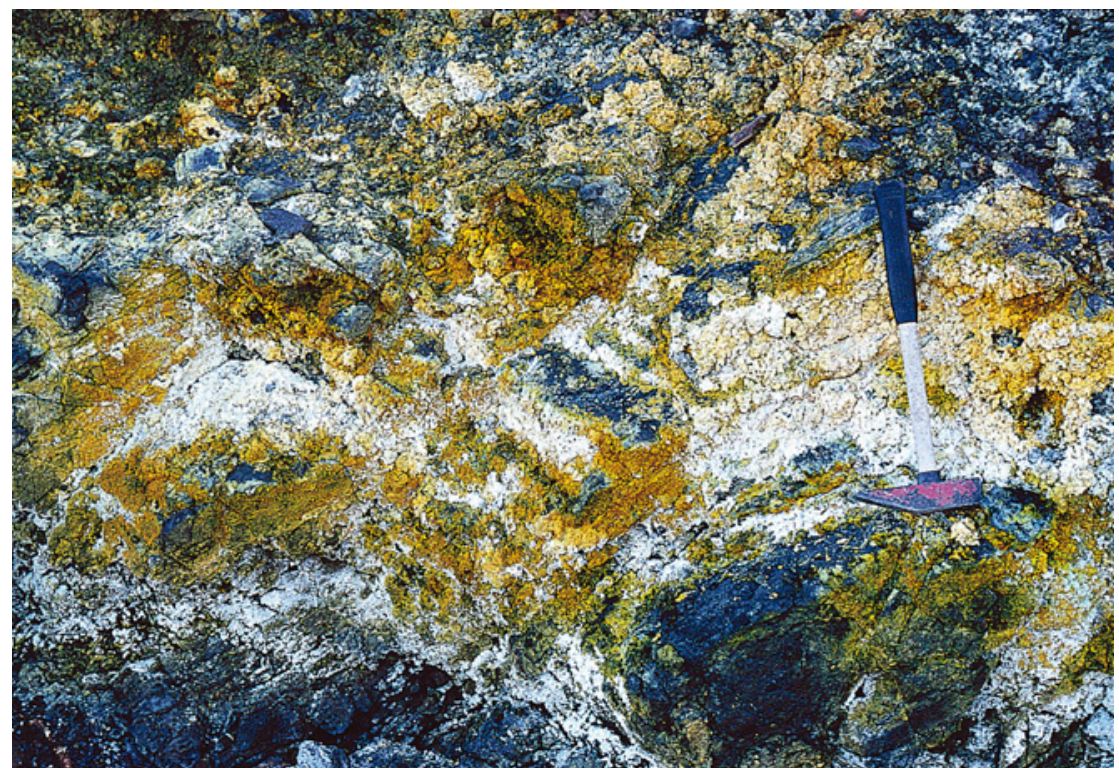

Fig. 20. Strongly pyritized and gossanous carbonate debris flow in exposures immediately west of the mouth of Citronen Fjord in the West gossan area. The hammer is $40 \mathrm{~cm}$ long. For location, see Fig. 3.

or very low zinc values, occur within the massive pyrite although more zinc-rich disseminated sulphides are present in overlying arenites and siltstones. The tonnage potential of this massive pyrite sheet, as indicated by three drill holes and on the basis of the outline of a pronounced gravity anomaly, is probably in the order of 30 million tons.

The textures and composition of the massive sulphides, viz. dense, no dendrites, low zinc and weakly enhanced lead values, and the hosting lithologies, viz. slumping, tectonic brecciation, high amount of quartzarenites and polymict, matrix-supported debris flows with generally rounded, lenticular clasts, are strikingly different from those in the Beach, Esrum and Discovery areas. It is assumed that the nearby Harder Fjord Fault Zone has played an active role during syn- and post-sedimentary processes and might have facilitated sulphide genesis in the West gossan area.

\section{Post-sedimentary mineralization}

Evidence of post-sedimentary, epigenetic mineralization is commonly seen in drill cores and rock exposures of especially the Middle and Hangingwall debris flows (Units 7 and 9). This later stage mineralization also left its traces on the stratiform massive sulphides, giving rise to a both laterally and vertically irregular pattern of zinc/lead enrichment.

An important area of post-sedimentary mineralization was found in 1996 in the Discovery area during 'fill-in' drilling and field-named 'Zone XX' (Figs 3, 21).
The zone is formed by a 20-30 m wide and up to 30 $\mathrm{m}$ thick corridor of strongly mineralized carbonate conglomerate that forms part of the Middle and/or Hangingwall debris flow (Units 7 and 9). It occurs along the northern side of a tectonic lineament which probably acted as a channel-way for metal-bearing fluids. This linear feature is partly exposed at surface and further traceable on the basis of drill core data. It can be followed over a strike length of about $1 \mathrm{~km}$ (see section 'Regional geology') and in a direction which is subparallel to the strike of the Trolle Land Fault Zone.

Zone XX clearly shows the irregular and discontinuous character of this mineralizing event which genetically was closely related to a process of penetrative dolomitization and minor silicification of the debris flow. This resulted in typical replacement textures with associated fading and locally bleaching of the clast-supported fabric with the subsequent accentuation of the original carbonate clasts by colloform linings of pyrite. This initial stage of replacement continues gradually into an increasingly massive pyritic sulphide with dendritic textures and floating 'clasts' of recrystallized carbonate. Solution vugs with or without secondary fillings of sparry dolomite and/or bitumen are commonly developed. Veins and veinlets of quartz/carbonate are numerous and they occasionally result in a stockworklike pattern.

The occurrences of abundant secondary, light brown to green-grey sphalerite and minor galena are restricted to certain well-defined intervals in the highly pyritic carbonate rocks of the Middle and Hangingwall debris flows. 


\section{Type of ore genesis}

The Citronen Fjord massive sulphides form a stratiform deposit displaying clear evidence of deposition on the sea floor contemporaneously with the enclosing sediments. It is interpreted to have formed at relatively low temperatures by the precipitation of sulphides from metal-bearing fluids introduced onto the sea floor from underlying fractures. It is thus placed in the sedimentary-exhalative class or SEDEX class of sulphide deposits (Large 1981; Carne \& Cathro 1982; Goodfellow et al. 1993). Sulphur isotope compositions of the sulphides suggest that the sulphur in the more distal parts of the mounds is mainly derived from sea water while in recrystallized parts, the sulphides have a component of hydrothermally transported sulphur (Kragh et al. 1997).

The Selwyn Basin sulphide deposits in the Canadian Cordillera show close similarity in geological setting and morphology to the Citronen Fjord zinc-lead occurrence. SEDEX mineralization in the Selwyn Basin has been identified within three separate ages of shale, ranging from Early Cambrian (Faro) through Early Silurian (Howards Pass) to Upper Devonian (Tom). Like the Citronen Fjord deposit, the Howards Pass deposits (XY and Anniv) are characterized by a high degree of sedimentary intercalation, a preponderance of zinc sulphides with respect to lead, low silver, copper and barium values, a weakly zoned nature of the mineralization, and the apparent absence of an identifiable feeder zone (Carne \& Cathro 1982). These deposits are thought to have formed in Early Silurian time at relatively low temperatures $\left(<220^{\circ} \mathrm{C}\right)$ from metalliferous chlorite-bicarbonate brines discharged at the surface of an epicratonic sub-basin along local extensional faults (Carne \& Cathro 1982; Goodfellow \& Jonasson 1986).

Significant components of the SEDEX depositional model include the existence of a tensional tectonic regime, deep-seated fractures, and a restricted basin morphology. The tensional tectonic regime provides not only the mechanism for basin subsidence, but also an enhanced heat flow, which is presumed to be the 'engine' that drove the fluid migration necessary to transport metals to the sea floor. Deep-seated fractures act as conduits for fluid migration, and the restricted sub-basin morphology provides the physical trap to contain the precipitated sulphides.

The mound-like accumulations of massive to dendritic-textured pyrite at Citronen Fjord are interpreted to represent vent-facies deposition with the bedded

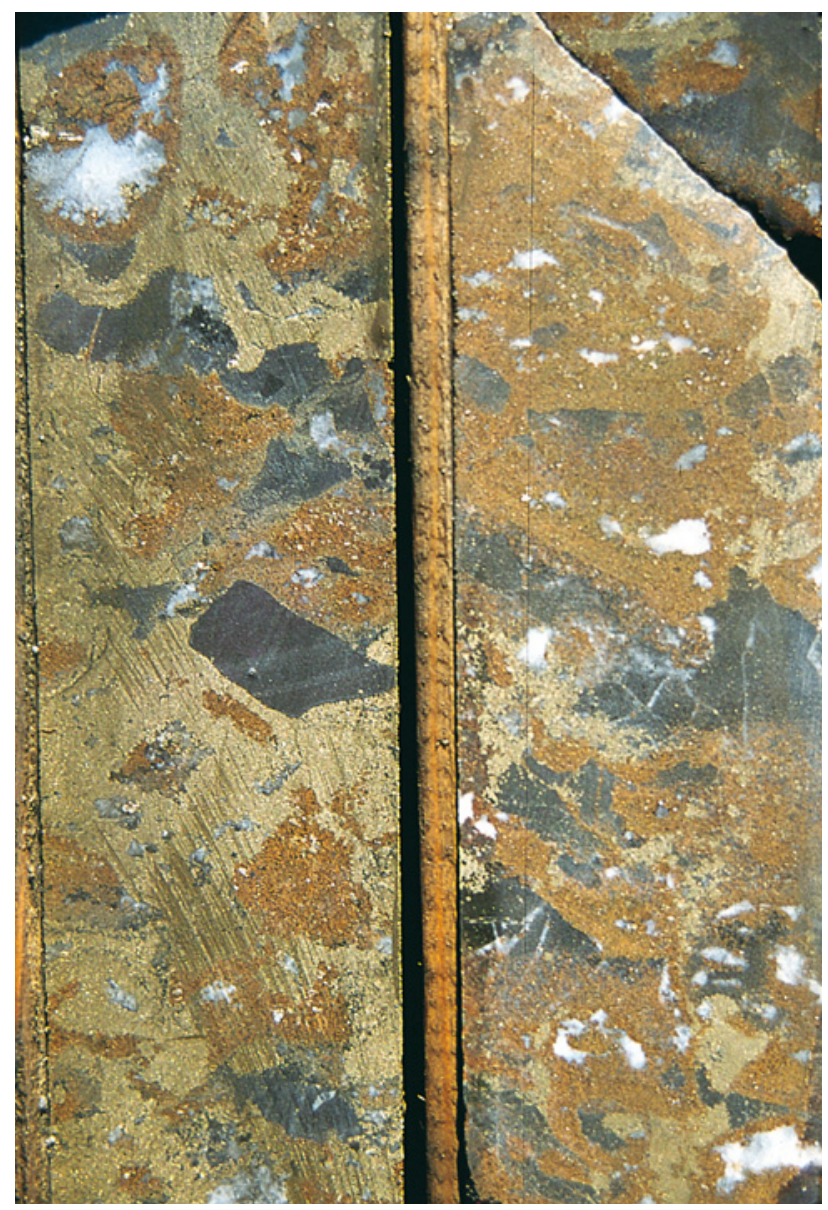

Fig. 21. Post-sedimentary sulphide mineralization in carbonate breccia. Brecciated massive pyrite with preserved mudstone clasts and vugs of sparry dolomite from Zone XX. Platinova drill-core CF96-96. The cores are $3.6 \mathrm{~cm}$ across. For location of Zone XX, see Fig. 3. Photo: Karsten Kragh.

sulphides representing the corresponding distal facies. In this model the position of mounds of massive sulphides should therefore indicate the locus of sea-floor vents.

The clear spatial association of sedimentary exhalative sulphides and carbonate debris flows at Citronen Fjord is noteworthy. The debris flows are a reflection of a particular tectonic regime - the break-up of the carbonate platform to the south along the inferred Navarana Fjord Escarpment - while the occurrence of several intervals of such rocks indicates repetition of tectonic events. Although the debris flows themselves are not considered to have a direct genetic role in the formation of the sulphides, it is probable that the tectonic events that initiated the debris flows were also responsible for localizing the metal-bearing fluids on the sea floor. 


\section{Structural geology}

The pattern of deposition within the Franklinian Basin during Early Palaeozoic time was dominated by the facies boundary of which the latest stage is termed the Navarana Fjord Escarpment. This tectonostratigraphic lineament (also called the Navarana Fjord Lineament, e.g. Higgins et al. 1991a; Soper \& Higgins 1991) was probably controlled by a deep-seated structure that was active from late Proterozoic until late Silurian time (Surlyk 1991).

Superimposed upon this regional pattern of deposition were two periods of Palaeozoic tectonism, the Caledonian in latest Silurian to Devonian time, and the Ellesmerian in Devonian to Carboniferous time. In addition, there are two dislocations of regional extent that have played an important role in the geological evolution of the Citronen Fjord area, viz. the E-W-trending Harder Fjord Fault Zone (HFFZ) and the NW-SEtrending Trolle Land Fault Zone (TLFZ) that intersect the inferred Navarana Fjord Escarpment in the general region of Citronen Fjord (Fig. 22).

\section{Caledonian Orogeny}

Initiation of Caledonian deformation was manifested by the deposition of the Merqujôq Formation sandstone turbidites, the source area for which was the rising Caledonian mountains to the east (Hurst 1980; Hurst \& Surlyk 1982; Surlyk \& Hurst 1984; Higgins et al. 1991a, b; Surlyk 1991). By late Silurian time, progressive uplift led to westerly-directed thrust faulting. This early Caledonian thin-skinned, thrust-fault deformation phase was named the 'Vølvedal orogeny' by Pedersen (1986) and is manifested in the Vølvedal area of Amundsen Land bounded approximately by the Harder Fjord Fault Zone to the north and by the southern shore of Frederick E. Hyde Fjord (Fig. 22). The thrust faults emanate within the Cambrian deep-water mudstone strata (the Frigg Fjord mudstone of the Polkorridoren Group) and displace overlying Ordovician and Silurian sediments.

The main tectonic transport direction was to the west with refraction toward the south-west along the buried Lower Silurian platform margin formed by the Navarana Fjord Escarpment. The west-directed displacement is estimated to be in the order of 80 to $100 \mathrm{~km}$, such that Ordovician sediments, now exposed around the inner reaches of Frederick E. Hyde Fjord, would have originated near the mouth of the fjord. This thrust fault deformation is interpreted as a foreland deformation related to the Caledonian succession of sinistral transport events along an $\mathrm{E}-\mathrm{W}$-trending megashear situated at the northern margin of the Franklinian Basin (Håkansson \& Pedersen 1982; Pedersen 1986).

The spectacular juxtaposition of the Cambrian and Silurian strata exposed in the north-eastern part of the Citronen Fjord area (Figs 1, 5), which is assumed to be due to low-angle thrusting, is thought most likely to have originated from this early Caledonian thrust-fault deformation.

\section{Ellesmerian Orogeny}

In northern Greenland, the Ellesmerian Orogeny caused north-to-south compression during late Devonian to early Carboniferous time producing prominent folds and thrusts and a number of approximately E-W trending tectonic zones (Soper \& Higgins 1987, 1991; Higgins et al. 1991a). Deformation and metamorphism diminish from north to south and extend as far as the Navarana Fjord Escarpment.

North of the Navarana Fjord Escarpment three tectonic zones have been defined: from south to north, the thin-skinned, fold and thrust zone; the divergence and imbricate zone; and in the north, the orthotectonic zone. The Citronen Fjord area is located at the convergence of the southerly two tectonic zones, while the orthotectonic zone forms the northern coast of Frederick E. Hyde Fjord but $5 \mathrm{~km}$ distant on the northern side of the Harder Fjord Fault Zone (Fig. 22; see Higgins et al. 1991a, fig. 65). The stable platform to the south of the escarpment remained essentially undeformed during the Ellesmerian Orogeny.

\section{Harder Fjord Fault Zone}

The Harder Fjord Fault Zone seems to have been a significant structural feature during both Caledonian and Ellesmerian deformation, and was presumably repeatedly active up to Tertiary or even Recent times. Dextral strike-slip movement of a few tens of kilometres associated with dyke emplacement and volcanic 


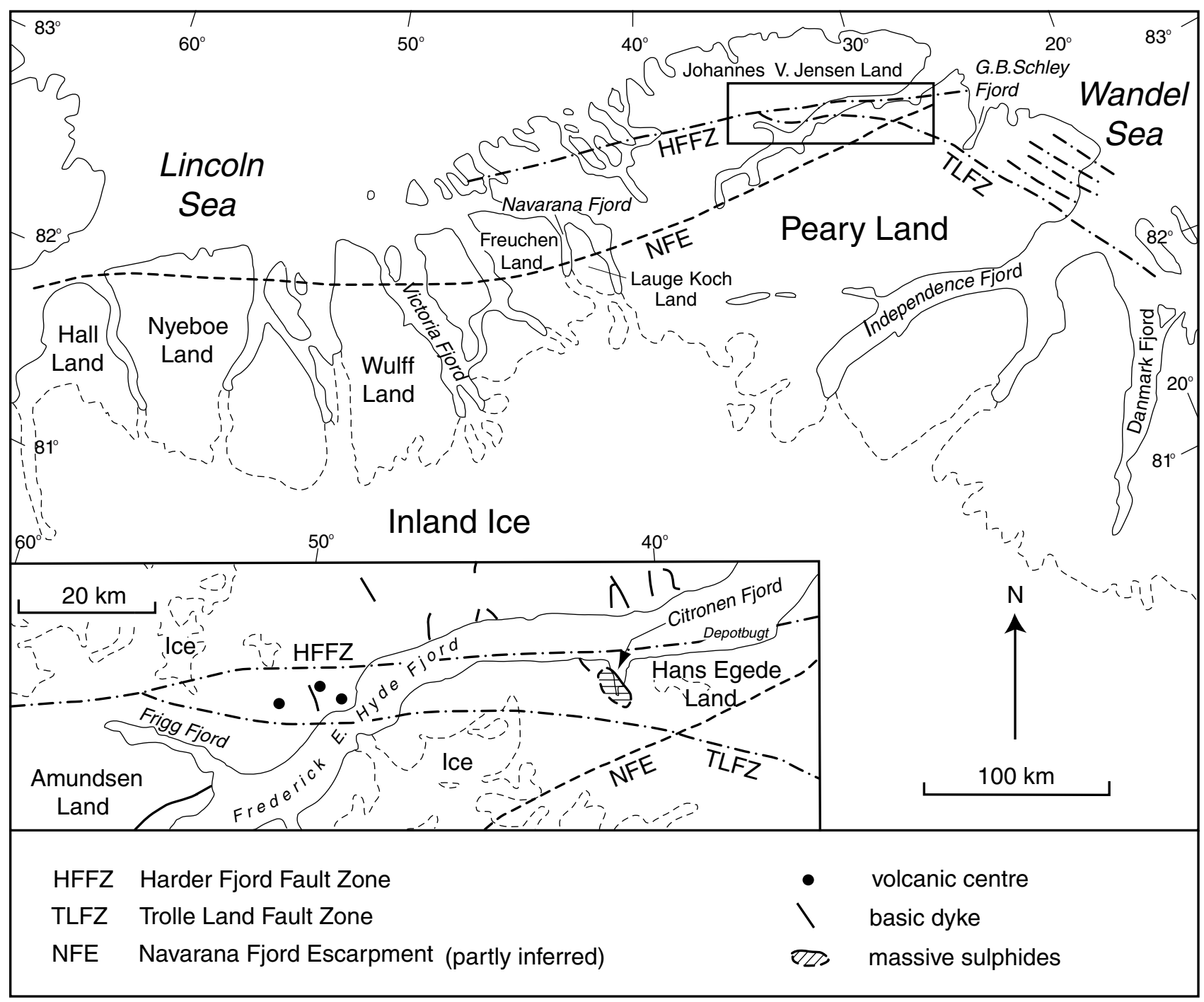

Fig. 22. Map of northern Greenland showing the structural setting of the Citronen Fjord sulphide deposit north of the Navarana Fjord Escarpment and at the junction of important fault zones. Data taken from various published papers by the Geological Survey of Greenland. Midtkap is the cape on Frederick E. Hyde Fjord containing the easternmost volcanic centre.

activity is interpreted to have taken place during the Cretaceous-Tertiary, with later Tertiary vertical uplift of possibly as much as $1-2 \mathrm{~km}$ on the north side of the fault (Soper \& Higgins 1987).

The eastern continuation of the Harder Fjord Fault Zone along Frederick E. Hyde Fjord between Midtkap and Depotbugt is inferred by the sharp outline of the southern shoreline. Furthermore, as suggested in this paper, the effects of the fault zone are also seen by the somewhat unusual lithological and textural characteristics of the Ordovician strata (i.e. Unit 7: Middle debris flow) that are exposed in the West gossan area (see section 'Stratigraphy of the Citronen Fjord area', p. 19).

\section{Trolle Land Fault Zone}

The Trolle Land Fault Zone is a prominent NW-SWtrending structure that cuts across the eastern end of Peary Land and forms the western border of the Wandel Sea Basin, which contains sediments of Carboniferous to Tertiary age (Håkansson \& Pedersen 1982). The fault zone appears in the Citronen Fjord area as a prominent lineament that on aerial photographs can be traced in a west to north-west direction as far as the area opposite Midtkap along Frederick E. Hyde Fjord (Fig. 22). Across the fjord immediately west of Midtkap the structure continues until it eventually merges with the Harder Fjord Fault Zone at a point north of Frigg Fjord 


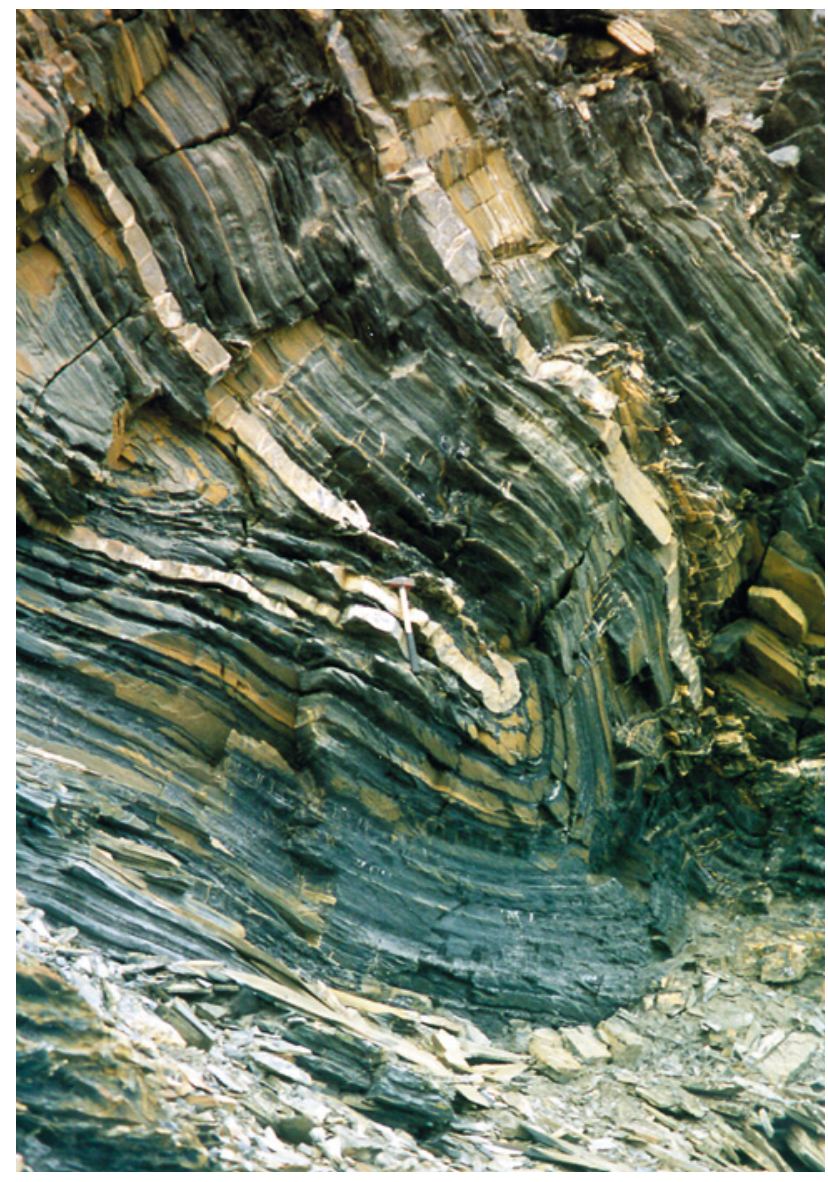

Fig. 23. Tightly folded calcareous siltstones of the Citronens Fjord Member in the hinge zone of the recumbent fold structure shown in Figure 4 on the west side of Citronen Fjord. Slaty cleavage is visible. The hammer is $40 \mathrm{~cm}$ long.

(Pedersen 1980; Fig. 22). This suggests that the Trolle Land Fault Zone originally developed as a splay of the Harder Fjord Fault Zone.

Within the structural wedge formed by the Harder Fjord Fault Zone and the Trolle Land Fault Zone, a number of volcanic centres occur (Pedersen 1980; Parsons 1981; Fig. 22). A Middle Devonian K/Ar age of $380 \pm 5 \mathrm{Ma}$ has been obtained from a sample taken from one of the intrusive bodies, suggesting an origin that is time-related to the Vølvedal orogeny (Pedersen \& Holm 1983). Although more investigations of the genesis and age of these intrusives are clearly warranted, it does seem likely that their emplacement was controlled by the convergence of the two fault zones. However, the apparent discrepancy in timing between the intrusive events and the genesis of the massive sulphides at Citronen Fjord does not lend support to a direct genetical relationship.

\section{Structural elements in the Citronen Fjord area}

As described in the section 'Regional geology' (p. 13), the Citronen Fjord area is located at the southern margin of the North Greenland Fold Belt. In the northern part of the area around Frederick E. Hyde Fjord, strata are recumbently folded and thrusted; to the south folding is less intense, and homoclinal strata occur just south of the map area (see Fig. 1).

\section{General fold style}

The structural style in the northern part of the Citronen Fjord area is characterized by the occurrence of largescale, approximately E-W-trending moderately inclined to recumbent, close to tight folds with north-dipping axial planes and sub-horizontal fold axes. A well-exposed example of a south-verging recumbent fold pair is seen in exposures of the Hangingwall debris flow (Unit 9) on the western side of Citronen Fjord (Dawes \& Soper 1979, fig. 12; Figs 4, 23). Drill hole information as well as field observations confirm that this structure is persistent in both the underlying Footwall shale (Unit 8) and the overlying Calcareous siltstone (Unit 10, see Fig. 6).

The mountain complex immediately west of the fjord is framed by a series of very large reclined, south-verging anticlinal/synclinal fold structures (Figs 6, 24). A major hinge area with associated thrust faults strikes parallel to the trend of 'West Elv' and explains a well-developed linear feature that is visible on aerial photographs. It is assumed that these fold structures continue eastwards to correlate directly with fold structures observed along the valley of 'East Elv'.

In the north-eastern map quadrant, some large-scale reclined fold structures were recognized by detailed mapping of the relatively easily traceable Cigar debris flow (Unit 2) and the overlying Calcareous siltstone (Unit 10; see Fig. 6).

In the less-deformed southern part of the area, moderately inclined to recumbent, open to tight folds with predominantly north-dipping axial planes and sub-horizontal, E-W-trending fold axes occur in more restricted areas (Fig. 25).

A stereographic projection of poles to bedding (Fig. 27a) indicates folding along flat-lying, ESE-trending fold axes (azimuth $107^{\circ}$ ).

A slaty cleavage $\left(\mathrm{S}_{1}\right)$ is often well developed in areas of more intense folding (Figs 23, 26) but is weak 
Fig. 24. Large-scale recumbent southverging pair of tight folds in sandstone turbidites (Unit 12) at the south-western end of Citronen Fjord. The height of the mountain is about $950 \mathrm{~m}$ a.s.l. with the shoreline just visible

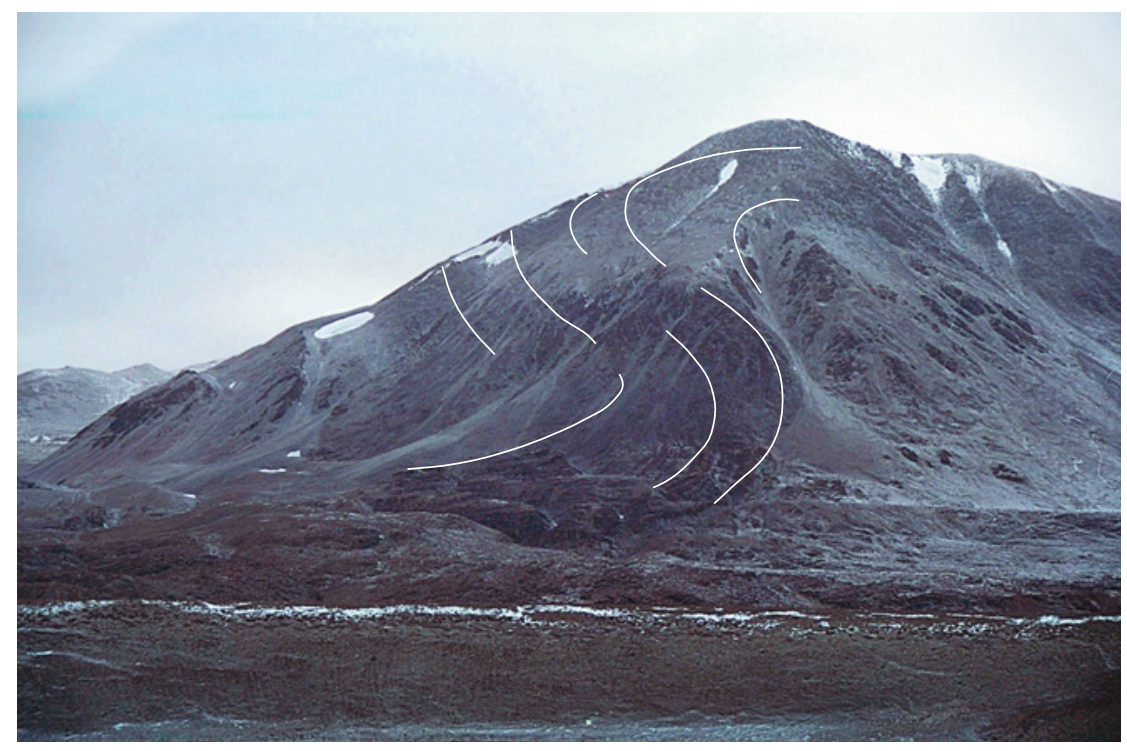

or absent in less disturbed areas. A $\pi$-diagram of $S_{1}$ measurements (Fig. 27b) shows a preferred dip and dip direction of approximately $70^{\circ}$ towards $217^{\circ}$. The zone axis of the cleavage trends $127^{\circ}$, indicating a minor deviation of about $20^{\circ}$ with the constructed $\mathrm{F}_{1}$ fold axis (cf. Fig. 27a).

These results correspond well with the structural analysis of the fold belt in the north-western part of Hans Egede Land by Pedersen (1979) who explained the deviation in direction between the zone axis of the cleavage and the constructed fold axis by a model of changing deformational parameters during the structural evolution of the fold belt.

\section{Thrust faults}

Large-scale fold structures and regional thrust faults occurring in the northern area along Frederick E. Hyde Fjord reflect the regional geometry of the North Greenland Fold Belt. In the north-eastern part of the study area, Cambrian and Silurian sediments are in direct paraconformable contact. In spite of the absence of categoric tectonic textures in rock exposures along this contact (see discusssion under 'Stratigraphy of the Citronen Fjord area', p. 17), the boundary is interpreted as a thrusted contact because of the age of the strata involved, and the presence of Ordovician strata nearby.
Fig. 25. Gentle to open folds in sandstone turbidites of Unit 12 north of Esrum Elv. Carbonate debris flow conglomerates of the Upper debris flow (Unit 11) outcrop in the lower right corner. West of the mouth of Esrum Elv; the stretch of river shown is $c .100 \mathrm{~m}$.

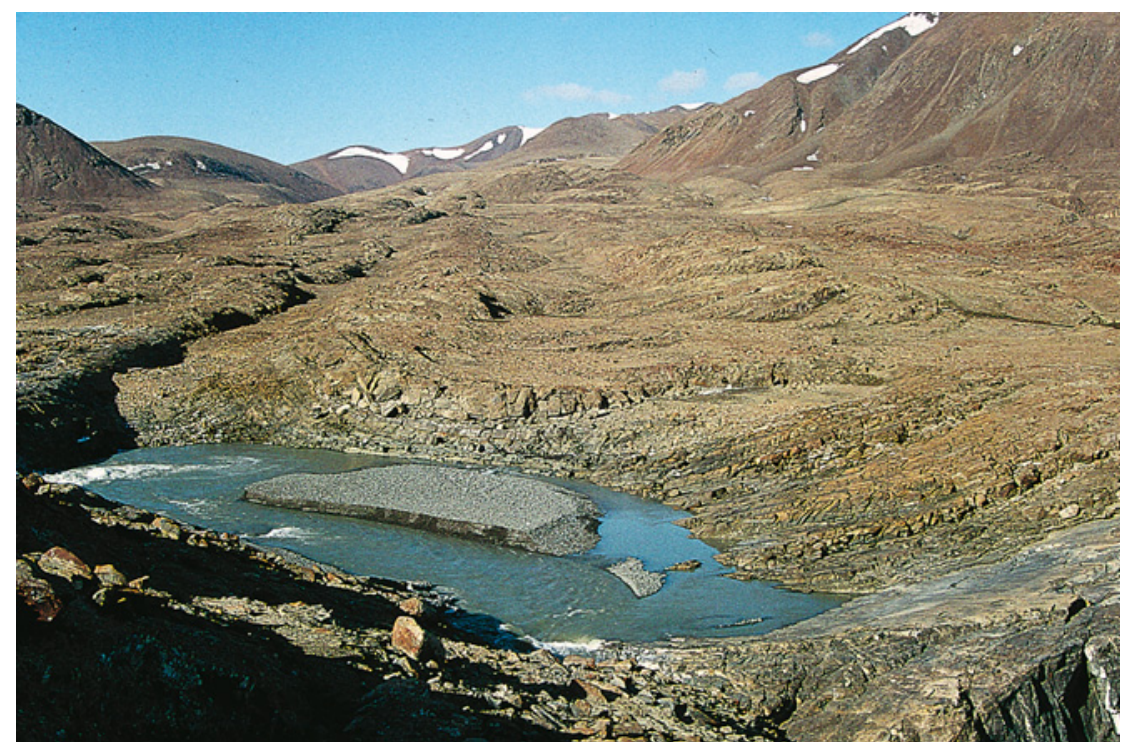




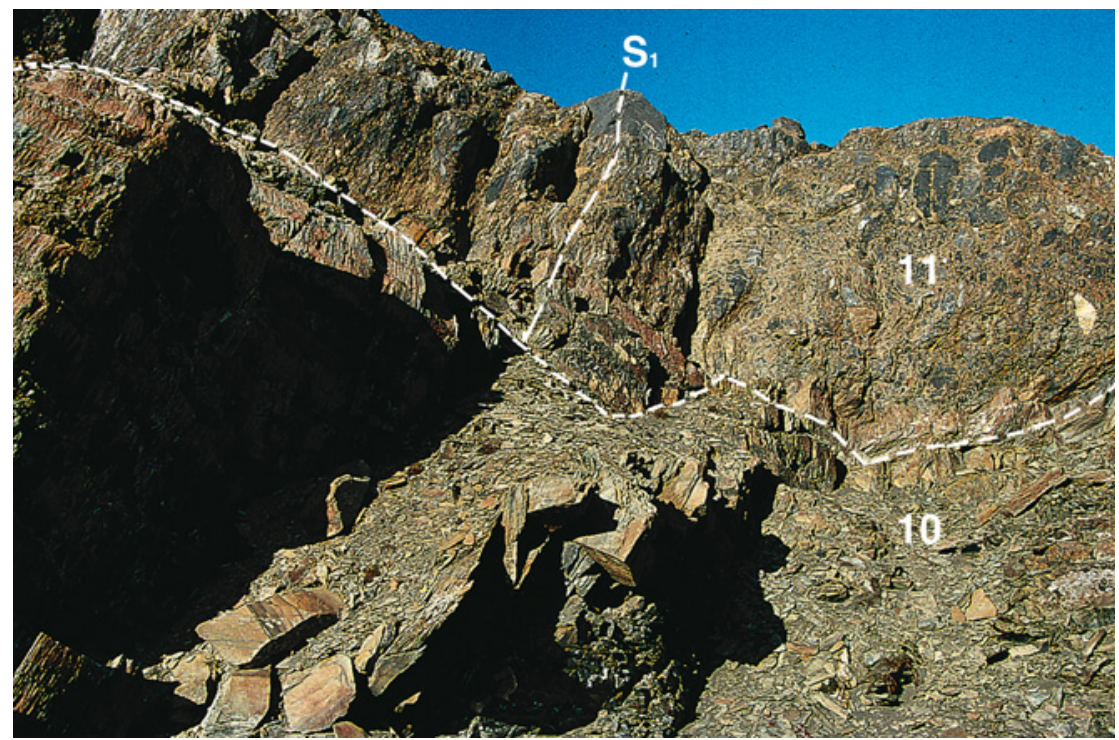

Fig. 26. Well-developed slaty cleavage $\left(\mathrm{S}_{1}\right)$ in calcareous siltstones (Unit 10) and overlying carbonate debris flow conglomerates of the Upper debris flow (Unit 11). Thickness of the debris flow is about $8 \mathrm{~m}$. South-east of type locality of the Citronens Fjord Member; for location, see Fig. 3.

The thrusting event leading to the juxtaposition of these Cambrian and Silurian strata must have pre-dated the deformation phase that resulted in the large-scale reclined fold structures since these clearly overprint this contact. This indicates a corresponding structural origin as described for the Early to Middle Devonian thrust faults in the Vølvedal region, Amundsen Land, some $100 \mathrm{~km}$ to the west of Citronen Fjord (Fig. 22; Pedersen 1986).

On the western side of Citronen Fjord, the Cambrian siltstones have not been identified and, although exposures are not particularly good, the strata are assumed absent. This suggests that the tectonic slice does not extend across Citronen Fjord or, alternatively, it may have a more northerly strike and be indicative of a westerly-directed thrust faulting.

The southern limit of this structural wedge involving Cambrian strata is defined by an approximately NW-SE-trending, sub-vertical fault structure which is exposed along 'East Elv'. We have the impression that this important fault in reality is the down-folded continuation of the above thrust fault contact (Fig. 6). This gains support from the lack of any indications of faulting in exposures of Merqujôq Formation siltstones and sandstones on the mountain slope at the eastern end of the valley. On the contrary, there is in this area evidence of intense folding with axial directions parallel to the trend of this E-W valley (see section 'General fold style', p. 34).

In the north-western part of the study area in the West gossan area (Fig. 3), intraformational thrusts and thrust faults, generally associated with flat-lying recum- bent folds, are common within Amundsen Land Group mudstones and carbonate debris flows. Together with the abundance of different kinds of brecciation textures and observed facies changes (see section 'Stratigraphy of the Citronen Fjord area', p. 17), these features seem to confirm the inferred proximity of the Harder Fjord Fault Zone.

\section{Block faulting}

As evidenced by field observations and the drill hole information, the sub-surface stratigraphy is off-set by some major normal faults. The most important of these is detected approximately $600 \mathrm{~m}$ north of the small lake, c. $2 \mathrm{~km}$ to the south of Citronen Fjord, causing a southern downthrow of the stratigraphy in the order of $150 \mathrm{~m}$ (Fig. 5). The fault outcrops at the mouth of the Esrum Elv and in a gully in the cliff face north-west of the lake.

Most of the faults recognized in the map area have an ENE-WSW strike and they are clearly post-Ellesme rian in age. Faults with an observed strike-slip component generally have a strike of $105^{\circ}$ which corresponds to the orientation of both the Harder Fjord $\left(105^{\circ}\right)$ and Trolle Land $\left(105-120^{\circ}\right)$ Fault Zones. This direction also corresponds to the general strike of the stratigraphic units and fold axes of the area. It is assumed that most fractures exposed in the Citronen Fjord area are the product of interaction between these two fault systems during different stages of the structural geological history. 


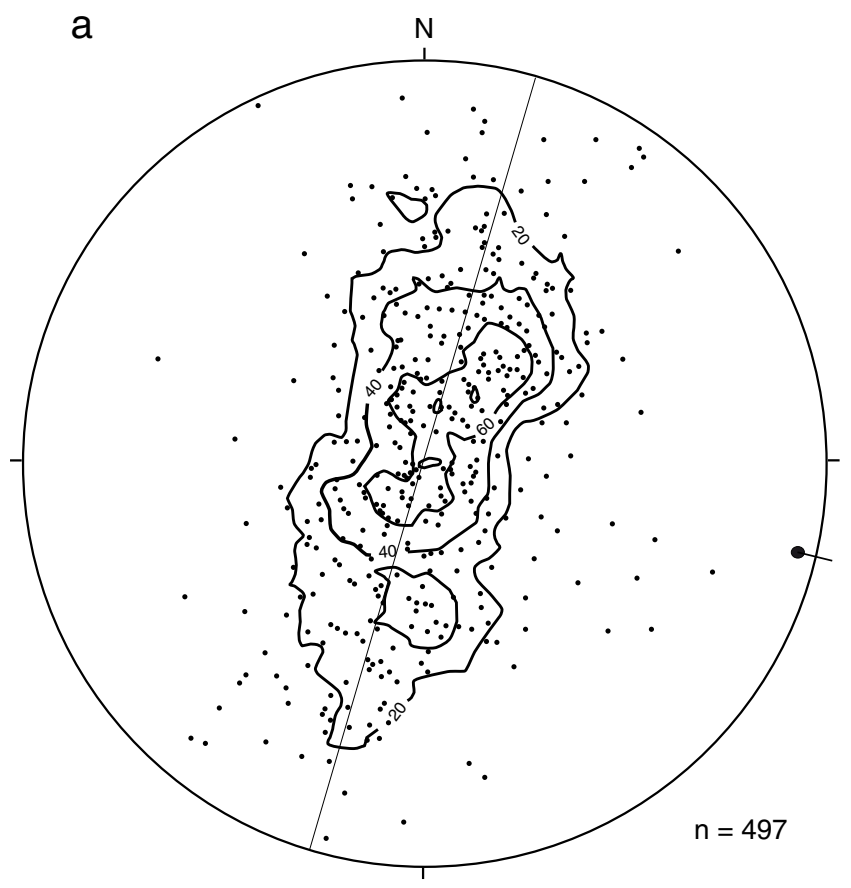

- Constructed fold axis

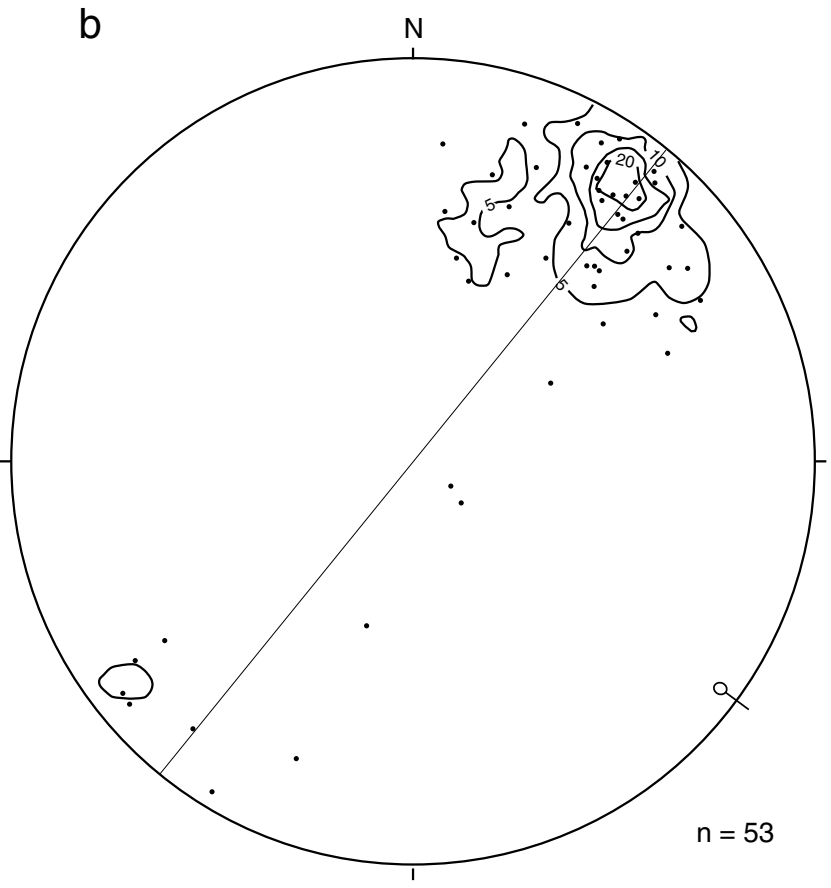

Q Zone axis of slaty cleavage

Fig. 27. Stereogram plots from the Citronen Fjord area: a, poles to bedding $\left(\mathrm{S}_{0}\right)$; b , poles to $\mathrm{S}_{1}$ cleavage. Equal area projection, lower hemisphere. The contours are percentages of the total sample points (497 and 53).

\section{Tectonic control of the massive sulphides}

The massive sulphide deposit in the Citronen Fjord area follows an overall trend of approximately $145^{\circ}$ azimuth. In places, a well-developed joint system occurs with fillings of coarse-grained calcite ( \pm quartz) and a common strike direction of $140-160^{\circ}$. These di-rections appear to be more northerly trending than the Trolle Land Fault Zone (105-120 ), the Harder Fjord Fault Zone $\left(105^{\circ}\right)$ and the trend of the dolerite dyke $\left(120^{\circ}\right)$ that has been described earlier from the northwestern quadrant of the map area. This slight difference in orientation may reflect the interaction between the Trolle Land and Harder Fjord Fault Zones. One result of this might be the development of conjugate shear fractures and associated extension and shear joints between these fault zones and this would have provided a maximum opportunity for fluid migration and enhanced heat flow. This tensional tectonic regime could have provided the mechanism for subsidence in which the sulphides eventually became trapped; in this case sub-basin subsidence.

From all the most recent accounts in the literature that have been quoted in this paper, the Navarana Fjord Escarpment can reasonably be projected to be located within $5 \mathrm{~km}$ to the south of the mineralization at Citronen Fjord. This palaeo-topographic structure is thought to have been persistent throughout much of Early Palaeozoic time, and is therefore presumed to be a tectonic, rather than a purely depositional feature. However, it is uncertain if the Navarana Fjord Escarpment was responsible in any direct way for the localization of the massive sulphides at Citronen Fjord; an assumption that was considered very likely at the time of the discovery and during the early exploration of the deposit.

\section{Acknowledgements}

We are particularly grateful to Peter R. Dawes at the Geological Survey of Greenland and Denmark (GEUS) for his help and critical review that led to considerable improvement of the initial manuscript, and for editing and help with illustrations. The line-drawings were all drafted by Alice Rosenstand at GEUS. Also appreciated 
are the inspiring discussions with Peter in 1992 about the geology, and the feasibility of a spring skidoo expedition to the Frederick E. Hyde Fjord region.

Stefan Bernstein and Guy Della Valle are thanked for their invaluable participation in the 1993 expedition that resulted in the discovery of the massive sulphides at Citronen Fjord.

We also acknowledge the geological information received from Stig A. Schack Pedersen and Mogens Lind (GEUS) in the planning stage of the 1993 expedition. Karsten Kragh (GEUS) is thanked for his assistance and discussions in the field and for allowing illustration of sulphide textures from an unpublished report. Discussions on North Greenland geology with other geologists at GEUS, including Martin Ghisler, Niels Henriksen, Tony Higgins and Agnete Steenfelt are appreciated.

We also direct our thanks to Merete Bjerreskov (Geological Museum, Copenhagen) for the determination of graptolites and to Arne Thorshøj Nielsen (Geological Museum, Copenhagen) and Jan Bergström (Swedish Museum of Natural History, Stockholm) for their identification of the Olenellus svalbardensis Kielan from Citronen Fjord.

Finally, the paper benefitted from thorough reviews by Stig A. Schack Pedersen and Don F. Sangster.

\section{References}

Bengaard, H.-J. \& Henriksen, N. 1986a: Geological map of Greenland, 1:500 000, Peary Land, sheet 8. Copenhagen: Geological Survey of Greenland.

Bengaard, H.-J. \& Henriksen, N. 1986b: Geological map of North Greenland, 1:100 000. In: Peel, J. S. \& Sønderholm, M. (eds): Sedimentary basins of North Greenland. Bulletin Grønlands Geologiske Undersøgelse 160 (loose map).

Bjerreskov, M. \& Poulsen, V. 1973: Ordovician and Silurian faunas from northern Peary Land, North Greenland. Rapport Grønlands Geologiske Undersøgelse 55, 10-14.

Blaker, M.R. \& Peel, J.S. 1997: Lower Cambrian trilobites from North Greenland. Meddelelser om Grønland Geoscience 35, $145 \mathrm{pp}$.

Bøggild, O.B. 1917: Grönland. In: Steinmann, G. \& Wilckens, O. (eds): Handbuch der regionalen Geologie 4, 38 pp. Heidelberg: Carl Winter.

Carne, R.C. \& Cathro, R.J. 1982: Sedimentary exhalative (sedex) zinc-lead deposits, northern Canadian Cordillera. Canadian Institute of Mining and Metallurgy Bulletin 75(840), 66-78.

Christie, R.L. \& Ineson, J.R. 1979: Precambrian-Silurian geology of the G. B. Schley Fjord region, eastern Peary Land, North Greenland. Rapport Grønlands Geologiske Undersøgelse 88, 63-71.

Davies, W.E. 1972: Landscape of northern Greenland. CRREL Special Report 164, 67 pp.

Dawes, P.R. 1969: North Peary Land (Johannes V. Jensen Land), 92 pp. Unpublished field diary, Geological Survey of Greenland, Copenhagen.

Dawes, P.R. 1994: Themes in the promotion of Greenland's mineral resource potential. Rapport Grønlands Geologiske Undersøgelse 160, 22-27.
Dawes, P.R. \& Kerr, J.W. (eds) 1982: Nares Strait and the drift of Greenland: a conflict in plate tectonics. Meddelelser om Grønland Geoscience 8, 392 pp.

Dawes, P.R. \& Soper, N.J. 1973: Pre-Quaternary history of North Greenland. In: Pitcher, M.G. (ed.): Arctic geology. Memoir of the American Association of Petroleum Geologists 19, $117-134$.

Dawes, P.R. \& Soper, N.J. 1979: Structural and stratigraphic framework of the North Greenland fold belt in Johannes V. Jensen Land, Peary Land. Rapport Grønlands Geologiske Undersøgelse 93, $40 \mathrm{pp}$.

Ellitsgaard-Rasmussen, K. 1955: Features of the geology of the folding range of Peary Land, North Greenland. Meddelelser om Grønland 127(7), 56 pp.

Escher, J.C. \& Larsen, P.H. 1987: The buried western extension of the Navarana Fjord escarpment in central and western North Greenland. Rapport Grønlands Geologiske Undersøgelse 133, 81-91.

Fränkl, E. 1955: Rapport über die Durchquerung von Nord Peary Land (Nordgrönland) im Sommer 1953. Meddelelser om Grønland 103(8), 61 pp.

Friderichsen, J.D., Higgins, A.K., Hurst, J.M., Pedersen, S.A.S., Soper, N.J. \& Surlyk, F. 1982: Lithostratigraphic framework of the Upper Proterozoic and Lower Palaeozoic deep water clastic deposits of North Greenland. Rapport Grønlands Geologiske Undersøgelse 107, 19 pp.

Gibbon, W.A. 1991: Economic mineral resources, Arctic Islands. In: Trettin, H.P. (ed.): Geology of the Innuitian Orogen and Arctic Platform of Canada and Greenland. Geology of Canada 3, 533-539. Ottawa: Geological Survey of Canada (also The geology of North America E, Geological Society of America). 
Goodfellow, W.D. \& Jonasson, I.R. 1986: Environment of formation of the Howards Pass (XY) Zn-Pb deposit, Selwyn Basin, Yukon. In: Morin, J.A. (ed.): Mineral deposits of northern Cordillera. Canadian Institute of Mining and Metallurgy Special Volume 37, 19-50.

Goodfellow, W.D., Lydon, J.W. \& Turner, R.J.W. 1993: Geology and genesis of stratiform sediment-hosted (SEDEX) zinc-leadsilver sulphide deposits. In: Kirkham, R.V. et al. (eds): Mineral deposit modeling. Geological Association of Canada Special Paper 40, 201-251.

Håkansson, E. \& Pedersen, S.A.S. 1982: Late Palaeozoic to Tertiary tectonic evolution of the continental margin in North Greenland. In: Embry, A.F. \& Balkwill, H.R. (eds): Arctic geology and geophysics. Memoir Canadian Society of Petroleum Geologists 8, 331-348.

Hedberg, H.D. 1976: International subcommission on stratigraphic classification, terminology and procedure, $200 \mathrm{pp}$. London: John Wiley \& Sons.

Henriksen, N. 1992: Geological map of Greenland, 1: 500 000, Nyeboe Land, sheet 7, Peary Land, sheet 8. Descriptive text, 40 pp., 2 maps. Copenhagen: Geological Survey of Greenland.

Henriksen, N. \& Higgins, A.K. 1991: The North Greenland project. In: Peel, J.S. \& Sønderholm, M. (eds): Sedimentary basins of North Greenland. Bulletin Grønlands Geologiske Undersøgelse 160, 9-24.

Higgins, A.K., Ineson, J.R., Peel, J.S., Surlyk, F. \& Sønderholm, M. 1991a: Lower Palaeozoic Franklinian Basin of North Greenland. In: Peel, J.S. \& Sønderholm, M. (eds): Sedimentary basins of North Greenland. Bulletin Grønlands Geologiske Undersøgelse 160, 71-139.

Higgins, A.K., Ineson, J.R., Peel, J.S., Surlyk, F. \& Sønderholm, M. 1991b: Cambrian to Silurian basin development and sedimentation, North Greenland. In: Trettin, H.P. (ed.): Geology of the Innuitian Orogen and Arctic Platform of Canada and Greenland. Geology of Canada 3, 111-161. Ottawa: Geological Survey of Canada (also The geology of North America $\mathbf{E}$, Geological Society of America).

Higgins, A.K., Soper, N.J. \& Davis, N.C. 1992: Lower Palaeozoic outer shelf and slope lithostratigraphy, Franklinian basin, North Greenland. Open File Series Grønlands Geologiske Undersøgelse 92/8, 57 pp.

Hurst, J.M. 1980: Silurian stratigraphy and facies distribution in Washington Land and western Hall Land, North Greenland. Bulletin Grønlands Geologiske Undersøgelse 138, 95 pp.

Hurst, J.M. 1984: Upper Ordovician and Silurian carbonate shelf stratigraphy, facies and evolution, eastern North Greenland. Bulletin Grønlands Geologiske Undersøgelse 148, 73 pp.

Hurst, J.M. \& Surlyk, F. 1982: Stratigraphy of the Silurian turbidite sequence of North Greenland. Bulletin Grønlands Geologiske Undersøgelse 145, 121 pp.

Hurst, J.M. \& Surlyk, F. 1984: Tectonic control of Silurian carbonate-shelf margin morphology and facies, North Greenland. American Association of Petroleum Geologists Bulletin 68(1), $1-17$.

Jepsen, H.F. 1971: The Precambrian, Eocambrian and Early Palaeozoic stratigraphy of the Jørgen Brønlund Fjord area, Peary
Land, North Greenland. Bulletin Grønlands Geologiske Undersøgelse 96, 42 pp. (also Meddelelser om Grønland 192(2)).

Kragh, K. 1996: Geologisk setting og teksturelle undersøgelser af Citronen Fjord ekshalative sulfidforekomst, Nordgrønland, 62 pp. Unpublished report, Geologisk Institut, Aarhus Universitet, Danmark.

Kragh, K. 1997: Primary and diagenetic textures - signs of rapid growth of sulphide and carbonate in the Citronen Fjord sedimentary-exhalative zinc-lead deposit, North Greenland. In: Hall, A.J. et al. (eds): Mineral Deposits Studies Group, Annual general meeting incorporating AGM of IGCP 356 CarpathoBalkan metallogeny. Glasgow University, 8-11 January, 1997, Programme with abstracts 41-42.

Kragh, K., Jensen, S.M. \& Fougt, H. 1997: Ore geological studies of the Citronen Fjord zinc deposit, North Greenland: project 'Resources of the sedimentary basins of North and East Greenland'. Geology of Greenland Survey Bulletin 176, 44-49.

Large, D.E. 1981: Sediment-hosted submarine exhalative lead-zinc deposits - a review of their geological characteristics and genesis. In: Wolf, K.H. (ed.): Handbook of strata-bound and stratiform ore deposits 9, 469-507. Amsterdam: Elsevier.

Laursen, D. 1972: The place names of North Greenland. Meddelelser om Grønland 180(2), 443 pp.

Lind, M. 1993: 'Schacks showing', Citronens Fjord, North Greenland, 7 pp. Unpublished report, Geological Survey of Greenland, Copenhagen.

MINEX 1993: Major discovery of massive sulphides; Platinova rewarded for perseverance. Greenland MINEX News 3, 9-10. Copenhagen: Geological Survey of Greenland/Mineral Resources Administration.

Parsons, I. 1981: Volcanic centres between Frigg Fjord and Midtkap, eastern North Greenland. Rapport Grønlands Geologiske Undersøgelse 106, 69-75.

Pedersen, S.A.S. 1979: Structural geology of central Peary Land, North Greenland. Rapport Grønlands Geologiske Undersøgelse 88, 55-62.

Pedersen, S.A.S. 1980: Regional geology and thrust fault tectonics in the southern part of the North Greenland fold belt, north Peary Land. Rapport Grønlands Geologiske Undersøgelse 99, 79-87.

Pedersen, S.A.S. 1982: Structural analysis of the southern margin of the North Greenland fold belt in Peary Land, 230 pp. Unpublished thesis, University of Copenhagen, Denmark.

Pedersen, S.A.S. 1986: A transverse, thin-skinned, thrust-fault belt in the Paleozoic North Greenland Fold Belt. Bulletin of the Geological Society of America 97(12), 1442-1455.

Pedersen, S.A.S. \& Henriksen, N. 1986: Geological map of Greenland, 1:100 000, Nordkronen 82 Ø Nord. Copenhagen: Geological Survey of Greenland.

Pedersen, S.A.S. \& Holm, P.M. 1983: The significance of a Middle Devonian K/Ar age of an intrusive rock in the southern part of the North Greenland fold belt. Bulletin of the Geological Society of Denmark 31, 121-127.

Salvador, A. 1994: International stratigraphic guide. A guide to stratigraphic classification, terminology, and procedure, 214 pp. New York: John Wiley \& Sons. 
Soper, N.J. \& Higgins, A.K. 1987: A shallow detachment beneath the North Greenland fold belt: implications for sedimentation and tectonics. Geological Magazine 124(5), 441-450.

Soper, N.J. \& Higgins, A.K. 1991: Devonian - Early Carboniferous deformation and metamorphism, North Greenland: Deformation. In: Trettin, H.P. (ed.): Geology of the Innuitian Orogen and Arctic Platform of Canada and Greenland. Geology of Canada 3, 281-288. Ottawa: Geological Survey of Canada (also The geology of North America E, Geological Society of America).

Soper, N.J., Higgins, A.K. \& Friderichsen, J.D. 1980: The North Greenland fold belt in eastern Johannes V. Jensen Land. Rapport Grønlands Geologiske Undersøgelse 99, 89-98.

Soper, N.J., Dawes, P.R. \& Higgins, A.K. 1982: Cretaceous-Tertiary magmatic and tectonic events in North Greenland and the history of the adjacent ocean basins. In: Dawes, P.R. \& Kerr, J.W. (eds): Nares Strait and the drift of Greenland: a conflict in plate tectonics. Meddelelser om Grønland Geoscience 8, 205-220.
Stemmerik, L., Jensen, S.M., Korstgård, J., Schønwandt, H.K., Surlyk, F., Clausen, O.R., Fougt, H., Kragh, K., Langdahl, B.R. \& Therkelsen, J. 1996: Resources of the sedimentary basins of North and East Greenland - an integrated petroleum and ore geological research project. Bulletin Grønlands Geologiske Undersøgelse 172, 32-36.

Surlyk, F. 1991: Tectonostratigraphy of North Greenland. In: Peel, J.S. \& Sønderholm, M. (eds): Sedimentary basins of North Greenland. Bulletin Grønlands Geologiske Undersøgelse 160, 25-47.

Surlyk, F. \& Hurst, J.M. 1984: The evolution of the early Palaeozoic deep-water basin of North Greenland. Geological Society of America Bulletin 95, 131-154.

Surlyk, F. \& Ineson, J.R. 1992: Carbonate gravity flow deposition along a platform margin scarp (Silurian, North Greenland). Journal of Sedimentary Petrology 62, 400-410.

Trettin, H.P. 1991: Tectonic framework. In: Trettin, H.P. (ed.): Geology of the Innuitian Orogen and Arctic Platform of Canada and Greenland. Geology of Canada 3, 59-66. Ottawa: Geological Survey of Canada (also The geology of North America E, Geological Society of America). 


\section{Danmarks og Grønlands Geologiske Undersøgelse (GEUS) \\ Geological Survey of Denmark and Greenland \\ Thoravej 8, DK-2400 Copenhagen NV \\ Denmark.}

\section{Bulletin Gronlands Geologiske Undersogelse}

142 Silurian graptolites from Washington Land, western North Greenland. 1981. 58 pp. By M. Bjerreskov.

115.00

143 Stratabound copper-lead-zinc mineralisation in the Permo-Triassic of central East Greenland. 1982. $42 \mathrm{pp}$.

By B. Thomassen, L. B. Clemmensen \& H. K. Schønwandt.

144 Upper Jurassic bivalves from Milne Land, East Greenland. 1982. 126 pp.

By F. T. Fürsich.

145 Stratigraphy of the Silurian turbidite sequence of North Greenland. 1982. $121 \mathrm{pp}$. By J. M. Hurst \& F. Surlyk.

146 Paleocene gastropods from Nûgssuaq, West Greenland. 1983. 115 pp. By H. A. Kollmann \& J. S. Peel.

147 The stratigraphy of the Upper Jurassic and Lower Cretaceous sediments of Milne Land, central East Greenland. 1984. 56 pp.

By T. Birkelund, J. H. Callomon \& F. T. Fürsich.

148 Upper Ordovician and Silurian carbonate shelf stratigraphy, facies and evolution, eastern North Greenland. 1984. 73 pp.

By J. M. Hurst.

149 Benthic macroinvertebrate associations from the Boreal Upper Jurassic of Milne Land, central East Greenland. 1984. 72 pp.

By F. T. Fürsich.

150 Stratigraphy and structure of the Fiskenæsset Complex, southern West Greenland. 1985. 72 pp. By J. S. Myers.

151 The geology of the Qôrqut granite complex north of Qôrqut, Godthåbsfjord, southern West Greenland. 1985. 43 pp.

By C. R. L. Friend, M. Brown, W. T. Perkins \& A. D. M. Burwell.

152 Reaction between picrite magma and continental crust: early Tertiary silicic basalts and magnesian andesites from Disko, West Greenland. 1985. 126 pp.

By A. K. Pedersen.

153 The Kimmeridgian ammonite faunas of Milne Land, central East Greeenland. 1985. 56 pp. By T. Birkelund \& J. H. Callomon.

154 The early Archaean to Proterozoic history of the Isukasia area, southern West Greenland. 1986. 80 pp.

By A. P. Nutman.

155 Topographical and geological maps of Hall Land, North Greenland. Description of a computer-supported photogrammetrical research programme for production of new maps, and the Lower Palaeozoic and surficial geology. 1987. 88 pp.

By P. R. Dawes.

156 Stratabound scheelite and stratiform tourmalinites in the Archaean Malene supracrustal rocks, southern West Greenland. 1987. 26 pp.

By P. W. U. Appel \& A. A. Garde.

157 Geology and petrology of the Lower Tertiary plateau basalts of the Scoresby Sund region, East Greenland. 1989. 164 pp.

By L. M. Larsen, W. S. Watt \& M. Watt.

Edited by F. G. Christiansen.

159 Conodonts from the Upper Ordovician - Lower Silurian carbonate platform of North Greenland. 1990. 151 pp.

By H. A. Armstrong.

160 Sedimentary basins of North Greenland. 1991. 164 pp. (6 articles) Edited by J. S. Peel \& M. Sønderholm.

161 Functional morphology, evolution and systematics of Early Palaeozoic univalved molluscs. 1991. 116 pp. (2 articles) By J. S. Peel. 
162 Upper Cretaceous - Lower Tertiary decapod crustaceans from West Greenland. 1992. 46 pp.

By J. S. H. Collins \& H. Wienberg Rasmussen.

163 Upper Llandovery and Wenlock Cyrtograptus from the Silurian Peary Land Group,

North Greenland. 1992. 31 pp.

By M. Bjerreskov.

164 Acritarchs from the Lower Cambrian Buen Formation in North Greenland. 1993. 35 pp.

By G. Vidal \& J. S. Peel.

165 Lithostratigraphy of the continental Devonian sediments in North-East Greenland. 1993. 108 pp.

By H. Olsen \& P.-H. Larsen.

166 Dinoflagellate cyst stratigraphy of the Barremian to Albian, Lower Cretaceous,

North-East Greenland. 1993. 171 pp.

By H. Nøhr-Hansen.

167 Lithostratigraphic framework of the Upper Proterozoic Eleonore Bay Supergroup of East and North-East Greenland. 1993. 38 pp.

By M. Sønderholm \& H. Tirsgaard.

168 Sedimentary basin analysis of the continental Devonian basin in North-East Greenland. 1993. $80 \mathrm{pp}$.

By H. Olsen.

169 Palaeontology, stratigraphy and environmental setting of Middle Cambrian outer shelf deposits, North Greenland. 1994. 155 pp. (5 articles)

Edited by J. S. Peel.

170 Upper Cretaceous dinoflagellate cyst stratigraphy, onshore West Greenland. 1996. 104 pp. By H. Nøhr-Hansen.

171 Research Papers. Collection of scientific articles. 1996. 90 pp. (4 articles)

172 Report of Activities, 1995. 1996. 119 pp. (20 articles)

\section{Geology of Greenland Survey Bulletin}

173 Cambrian shelf stratigraphy of North Greenland. 1997. 120 pp.

By J. R. Ineson \& J. S. Peel.

174 The Proterozoic Thule Supergroup, Greenland and Canada: history, lithostratigraphy and development. 1997. 150 pp.

By P. R. Dawes.

175 Stratigraphy of the Neill Klinter Group; a Lower - lower Middle Jurassic tidal embayment succession, Jameson Land, East Greenland. 1998. 80 pp.

By G. Dam \& F. Surlyk.

176 Review of Greenland activities 1996. 1997. 112 pp. (18 articles)

Edited by A. K. Higgins \& J. R. Ineson.

177 Accretion and evolution of an Archaean high-grade grey gneiss - amphibolite complex: the Fiskefjord area, southern West Greenland. 1997. 115 pp.

By A. A. Garde.

178 Lithostratigraphy, sedimentary evolution and sequence stratigraphy of the Upper Proterozoic Lyell Land Group (Eleonore Bay Supergroup) of East and North-East Greenland. 1997. 60 pp. By H. Tirsgaard \& M. Sønderholm.

179 The Citronen Fjord massive sulphide deposit, Peary Land, North Greenland: discovery, stratigraphy, mineralization and structural setting. 1998. 40 pp.

By F. W. van der Stijl \& G. Z. Mosher.

180 Review of Greenland activities 1997. 1998.

Prices are in Danish kroner exclusive of local taxes, postage and handling

The series Geology of Greenland Survey Bulletin is a continuation of Bulletin Gronlands Geologiske Undersogelse and incorporates Rapport Gronlands Geologiske Undersogelse. These two series were issued by the former Grønlands Geologiske Undersøgelse (GGU) which was merged in 1995 with the former Danmarks Geologiske Unders $\varnothing$ gelse (DGU) to form a new national geological survey: Danmarks og Grønlands Geologiske Undersøgelse (The Geological Survey of Denmark and Greenland) with the pet-name GEUS. Two other scientific series are issued by GEUS: Geology of Denmark Survey Bulletin and Geology of Denmark and Greenland Map Series. 


\section{Danmarks og Grønlands Geologiske Undersøgelse (GEUS) \\ Geological Survey of Denmark and Greenland \\ Thoravej 8, DK-2400 Copenhagen NV \\ Denmark}

\section{Rapport Gronlands Geologiske Undersogelse}

111 A simple model of runoff from unguaged basins in West Greenland. 1982. 26 pp.

By R. J. Braithwaite.

40.00

112 Report on the geology of the Godthåbsfjord-Isukasia region. 1983. 127 pp. (10 articles)

113 Petrography and geochemistry of amphibolites from the Nordre Strømfjord area in the central part of the Nagssugtoqidian of West Greenland. 1983. 20 pp.

By F. C. Mengel.

114 Processing and interpretation of aeromagnetic data in The Geological Survey of Greenland. 1982. $42 \mathrm{pp}$.

By L. Thorning.

115 Report of Activities, 1982. 1983. 123 pp. (25 articles)

116 Tertiary volcanic rocks from Bontekoe $\varnothing$, East Greenland. 1983. 13 pp. By A. Noe-Nygaard \& A. K. Pedersen.

117 Origin of quartzo-feldspathic supracrustal rocks from the central part of the Nagssugtoqidian Mobile Belt of West Greenland. 1984. 26 pp.

By A. Rehkopff.

118 Greenschist facies metabasites from the Hellefiskefjord G. B. Schley Fjord area, eastern Peary Land, North Greenland. 1984. 17 pp.

By R. E. Bevins \& G. Rowbotham.

119 Precambrian gneisses and intrusive anorthosite of Smithson Bjerge, Thule district, North-West Greenland. 1984. 31 pp.

By A. P. Nutman.

120 Report of Activities, 1983. 1984. 121 pp. (21 articles)

121 Biostratigraphic studies in western North Greenland; Operation Grant Land 1965-1966. 1984. 103 pp. (6 articles)

122 Aeromagnetic maps of parts of southern and central West Greenland: acquisition, compilation and general analysis of data. 1984. 36 pp.

By L. Thorning.

123 The plutonic igneous and high-grade metamorphic rocks of southern Liverpool Land, central East Greenland, part of a supposed Caledonian and Precambrian complex. 1985. 39 pp.

By R. F. Cheeney.

124 Lithostratigraphy of the Tertiary Vaigat Formation on Disko, central West Greenland.

1985. 30 pp.

By A. K. Pedersen.

125 Report of Activities 1984. 1985. 114 pp. (26 articles)

126 Report on the 1984 geological expedition to central and western North Greenland. 1985. 128 pp. (13 articles)

127 Gardar dykes north of the Igaliko Syenite Complex, southern Greenland. 1985. 24 pp

By B. G. J. Upton \& J. G. Fitton.

128 Developments in Greenland geology. 1986. 169 pp. (13 articles)

Edited by F. Kalsbeek \& W. S. Watt.

129 Occurrences of anorthositic rocks in the reworked Archaean basement in the Umanak area, central West Greenland. 1986. 18 pp.

By M. C. Andersen \& T. C. R. Pulvertaft.

130 Report of Activities, 1985. 1986. 129 pp. (21 articles)

131 Quaternary, pre-Holocene, marine events of western Greenland. 1986. 23 pp. By M. Kelly.

132 North Greenland Lower Palaeozoic palaeontology and stratigraphy: short contributions. 1986. 123 pp. (14 articles)

Edited by J. S. Peel.

133 Report on the 1985 geological expedition to central and western North Greenland. 1987. 168 pp. (15 articles)

134 Geochronological studies in central East Greenland (four papers). 1987. 51 pp. 
135 Report of Activities, 1986. 1987. 105 pp. (18 articles)

136 Early Tertiary, low-potassium tholeiites from exploration wells on the West Greenland shelf. 1987. $25 \mathrm{pp}$

By N. Hald \& J. G. Larsen.

137 Cambrian-Jurassic fossils, trace fossils and stratigraphy from Greenland. 1988. 159 pp.

(11 articles)

Edited by $\mathrm{J}$. S. Peel.

160.00

138 Glacier-hydrological conditions on the Inland Ice north-east of Jakobshavn/Ilulissat,

West Greenland. 1988. 1 map with text.

By H. H. Thomsen, L. Thorning \& R. J. Braithwaite.

139 Etah meta-igneous complex and the Wulff structure: Proterozoic magmatism and deformation in Inglefield Land, North-West Greenland. 1988. 24 pp.

By P. R. Dawes.

140 Report of Activities, 1987. 1988. 124 pp. (31 articles)

141 Field occurrence and petrology of deformed metabasite bodies in the Rinkian mobile belt, Umanak district, West Greenland. 1988. 36 pp

By L. Schiøtte.

142 A pilot seismo-stratigraphic study on the West Greenland continental shelf. 1989. 16 pp. By J. A. Chalmers

143 North Greenland stratigraphy and petroleum geology. 1989. 71 pp. (3 articles)

100.00

144 Palaeozoic fossils and stratigraphy from North Greenland. 1989. 52 pp. ( 4 articles)

60.00

145 Report of Activities, 1988. 1989. 118 pp. (27 articles)

110.00

146 Geology of the Ammassalik region, South-East Greenland. 1989. 106 pp. (16 articles) Edited by F. Kalsbeek.

130.00

147 Lower Cambrian trace fossils from Greenland. 1990. 62 pp. (2 articles) Edited by J. S. Peel.

148 Current Research including Report of Activities, 1989. 1990. 141 pp. (28 articles)

85.00

160.00

149 Reservoir evaluation of Upper Permian buildups in the Jameson Land basin, East Greenland. 1991. 23 pp.

By L. Stemmerik.

150 Current Research. Short scientific papers. 1991.43 pp. (5 articles)

151 A stratigraphic section through the Silurian turbidite sequence (Peary Land Group)

in northern Nyeboe Land, North Greenland. 1991. 21 pp.

By P.-H. Larsen \& J. C. Escher.

40.00

152 Current Research including Report of Activities, 1990. 1991. 111 pp. (23 articles)

150.00

153 Quaternary geology of western and central North Greenland. 1992. 34 pp.

By M. Kelly \& O. Bennike.

154 Current Research. Short scientific papers. 1992. 59 pp. (4 articles)

100.00

70.00

155 Current Research including Report of Activities, 1991. 1992. 93 pp. (18 articles)

130.00

156 Geological analysis and mapping using multi-model photogrammetry. 1992. 72 pp. (8 articles)

Edited by K. S. Dueholm \& A. K. Pedersen.

140.00

157 Lithostratigraphy and geological setting of Upper Proterozoic shoreline-shelf deposits, Hagen Fjord Group, eastern North Greenland. 1992. 27 pp.

By L. B. Clemmensen \& H. F. Jepsen.

158 Glacier inventory and atlas of West Greenland. 1992. 194 pp.

By A. Weidick, C. E. Bøggild \& N. T. Knudsen.

180.00

159 Current Research including Report of Activities, 1992. 1993. 126 pp. (24 articles)

120.00

160 Report of Activities, 1993. 1994. 92 pp. (19 articles)

130.00

162 Geology of North-East Greenland. 1994. 209 pp. (19 articles) Edited by A. K. Higgins.

290.00

164 Current Research. Short scientific papers. 1994. 35 pp. (3 articles)

140.00

Prices are in Danish kroner exclusive of local taxes, postage and handling 